\title{
Plant Breeding for Harmony between Modern Agriculture Production and the Environment
}

\author{
João Carlos da Silva Dias \\ Instituto Superior de Agronomia, University of Lisbon, Lisbon, Portugal \\ Email: mirjsd@gmail.com
}

Received 10 December 2014; accepted 24 December 2014; published 16 January 2015

Copyright (C) 2015 by author and Scientific Research Publishing Inc.

This work is licensed under the Creative Commons Attribution International License (CC BY). http://creativecommons.org/licenses/by/4.0/

(c) $\underset{\mathrm{EY}}{0}$ Open Access

\section{Abstract}

The world population is estimated to be 9.2 billion in 2050 . To sufficiently feed these people, the total food production will have to increase $60 \%-70 \%$. Climate models predict that warmer temperatures and increases in the frequency and duration of drought during the present century will have negative impact on agricultural productivity. These new global challenges require a more complex integrated agricultural and breeding agenda that focuses on livelihood improvement coupled with agro-ecosystem resilience, eco-efficiency and sustainability rather than just on crop productivity gains. Intensifying sustainability agro-ecosystems by producing more food with lower inputs, adapting agriculture to climate change, conserving agro-biodiversity through its use, and making markets to work for the small farmers are needed to address the main issues of our time. Plant breeding has played a vital role in the successful development of modern agriculture. Development of new cultivars will be required while reducing the impact of agriculture on the environment and maintaining sufficient production. Conventional plant breeding will remain the backbone of crop improvement strategies. Genetic engineering has the potential to address some of the most challenging biotic constraints faced by farmers, which are not easily addressed through conventional plant breeding alone. Protective measures and laws, especially patenting, must be moderated to eliminate coverage so broad that it stifles innovation. They must be made less restrictive to encourage research and free flow of materials and information. Small farmers have an important role in conserving and using crop biodiversity. Public sector breeding must remain vigorous, especially in areas where the private sector does not function. This will often require benevolent public/private partnerships as well as government support. Active and positive connections between the private and public breeding sectors and large-scale gene banks are required to avoid a possible conflict involving breeders' rights, gene preservation and erosion. Plant breeding can be a powerful tool to bring "harmony" between agriculture and the environment, but partnerships and cooperation are needed to make this a reality. 


\section{Keywords}

\section{Breeding, Modern Agriculture, Climate Changes, Biodiversity, Environment, Ecosystems, Transgenic Crops, Small Farmers}

\section{Introduction}

There are now almost 7.25 billion human beings inhabiting this planet, and it has been projected that world population growth may exceed 70 million annually over the next 40 years. The world population will be approximately 9.2 billion in 2050, when the concentration of carbon dioxide and ozone will be $550 \mathrm{ppm}$ and 60 ppm, respectively and the climate will be warmer by $2^{\circ} \mathrm{C}[1]$. At that time it is expected that approximately $90 \%$ of this global population will reside in Asia, Africa, and Latin American countries [2] [3]. Currently, about 1 billion human beings suffer from hunger; 3 billion malnourished people suffer one or more micronutrient deficiencies (especially vitamin A, iodine and iron) and live with less than 2 US dollars per day; and anthropogenic climate change continues to affect food output and quality [4] [5]. By 2050, to sufficiently feed all these people, the total food production will have to increase $60 \%$ to $70 \%$ to meet a net demand of 1 billion tonnes of cereal for food and to feed, and 200 million tonnes of meat [6]-[8], depending on assumptions of population growth, income growth and dietary changes. This projected increase of global crop demand is partly due to a growing global population, but a larger driver is increasing global affluence and associated changes in diet due to higher incomes [4] [8]. As global incomes increase, diets typically shift from those comprised of mostly grains, to diets that contain more vegetables and fruits and a greater proportion of meat, dairy products, and eggs [4] [8]-[10].

This shift from plant-based diets to more intensive demand for animal products is termed as the "Livestock Revolution" [11] and it is estimated that approximately $40 \%$ of the world's population will undergo this revolution to more animal consumption by the year 2050 [8]. In order to meet these demands, global livestock production systems are shifting from using mostly waste products, crop residues, and marginal lands to more industrial systems which require less land and use of higher value feed crops [11] [12]. In developing countries with high rates of increasing animal product demands, a greater proportion of cereals are being directed towards animals [13]. Increasing demand for meat and dairy is also of importance to the global environment because their production requires more land and other resources than plant-based foods [14]-[16]. In fact, livestock production is the single largest anthropogenic use of land. According to a 2011 analysis, $75 \%$ of all agricultural land (including crop and pasture land) is dedicated to animal production [17]. Livestock production is also responsible for other environmental impacts. Livestock production is estimated to be responsible for $18 \%$ of total greenhouse gas emissions [18], and animal products generally have a much higher water footprint than plant-based foods [19].

In addition to growing meat and dairy demands, affluent nations are also directing a growing proportion of high-value feedstock to bio-fuel production. A great majority of bio-fuel feedstock are human-edible, especially from maize in the United States and sugarcane in Brazil. In 2010 global bio-fuel production represented 2.7\% of global fuel for road transportation (at 107 billion liters produced), which is more than a $450 \%$ increase from the year 2000 [20]. To produce these fuels the United States and Brazil combined dedicated over 460 million tonnes of maize and sugarcane, respectively, to bio-fuel production in 2010 , which is $6 \%$ of global crop production [21].

In 2008, the world's arable land amounted to $1386 \mathrm{M}$ ha, out of a total $4883 \mathrm{M}$ ha land used for agriculture [22]. Each year, arable and agricultural land is lost due to deforestation, overgrazing, agricultural activities, gathering and overexploitation for fuel-wood, urbanization and industrialization. The most direct negative impact of agriculture on biodiversity is due to the considerable loss of natural habitats, which is caused by the conversion of natural ecosystems into agricultural land. The arable land is limited. Increases in arable land can only be done by deforestation. Agricultural production should be increased without further deforestation. This requires innovation and better technologies, as well as substantial investment, to increase yields on existing agricultural land.

Climate models predict that warmer temperatures and increases in the frequency and duration of drought during the twenty-first century will have negative impact on agricultural productivity [23]-[28]. For example, maize 
production in Africa could be at risk of significant yield losses as researchers predict that each degree-day that the crop spends above $30^{\circ} \mathrm{C}$ reduces yields by $1 \%$ if the plants receive sufficient water [27]. These predictions are similar to those reported for maize yield in the United States [29]. Lobell et al. [27] further showed that maize yields in Africa decreased by $1.7 \%$ for each degree-day the crop spent at temperatures of over $30^{\circ} \mathrm{C}$ under drought. Wheat production in Russia decreased by almost one-third in 2010, largely due to the summer heat wave. Similarly, wheat production declined significantly in China and India in 2010, largely due to drought and sudden rise in temperature respectively, thereby causing forced maturity [30]. Warming at $+2^{\circ} \mathrm{C}$ is predicted to reduce yield losses by 50\% in Australia and India [31] [32]. Likewise, the global maize and wheat production, as a result of warming temperatures during the period of 1980 to 2008, declined by 3.8\% and 5.5\%, respectively [28]. So climate change poses a serious threat to species fitness [33] [34], and to agro-ecosystems essential to food production [35].

Climatic variation and change are already influencing the distribution and virulence of crop pest and diseases, but the interactions between the crops, pests and pathogens are complex and poorly understood in the context of climate change [36]. We will need to integrate plant biology into the current paradigm with respect to climate change to succeed in defeating emerging pests and pathogens posing a new threat to agriculture due to climate change [37]-[39].

In this context we can ask: can we feed and clothe the growing world population while simultaneously preserving or improving ecosystems and the natural environment?

History shows that modern agriculture has the potential to feed the world population but also to be worst and even catastrophically with the natural environment. Some examples are deforestation, overgrazing and erosion, in many parts of the world, which contributed to the outright collapse of ecosystems. One classical example is Madagascar's central highland plateau that has become virtually totally barren (about ten percent of the country), as a result of slash-and-burn deforestation, an element of shifting cultivation practiced by many natives. Intensification of production systems have also led to reduction in crop and livestock biodiversity, and increased genetic vulnerability and erosion. In contrast, the "Green Revolution", which began providing high-yielding crop cultivars and high-input management techniques to developing countries in the 1960s, has prevented mass starvation and improved living standards throughout the world [40]. Dwarfing, photoperiod insensitive genes and host plant resistance genes to pathogens and pests were bred for various crops during the "Green Revolution" [41]. Production in agriculture was increased in many nations of Asia and Latin America by the "Green Revolution". Crop yields in the developing world would have been at least $20 \%$ less and food prices about $19 \%$ higher than they were in 2000 without the innovations of the "Green Revolution" [42]. Calorie consumption would have dropped by about $5 \%$ and the number of malnourished children would have increasing by at least $2 \%$; i.e., the "Green Revolution" helped to improve the health status of 32 to 42 million pre-school children. Since the beginning of the "Green Revolution" in 1960, land devoted to crops increased some 10\%, land under irrigation has doubled, pesticide use by agriculture has tripled, fertilizer use is up 23-fold, pesticide use is up by a factor of 53. Nowadays, forty per cent of crop production comes from the $16 \%$ of agricultural land that is irrigated. Irrigated lands account for a substantial portion of increased yields obtained during the "Green Revolution". However, the global rate of increase in the irrigated area is declining, per capita irrigated area has declined by $5 \%$ since 1978, and new dam construction may allow only a 10\% increase in water for irrigation over the next 30 years [43]. The enhancement of yield achieved in the "Green Revolution" (29\% in food supplies per capita since 1960) may have been associated with an increased level of greenhouse gas emissions associated with higher fertilizer production and application, but, overall, its net effect has been calculated to have reduced $\mathrm{CO}_{2}$ emission by some 161 gigatons of carbon (GtC) over the period 1961-2005 [44], implying that gains in crop productivity can make a positive contribution to reducing greenhouse gas emissions.

Developing sustainable agriculture in environmentally sensitive systems is the great challenge of the coming decades. More food, animal feed, fiber, fuel, and forest products must be produced with less available land, water, and nutrients, to meet basic human needs and improve the sustainability of production [45]. In addition, pressure from an increasing global human population will necessitate more efficient and diversified land use. High crop yields of main staples will still be needed for freeing land to cash or more nutritious crops such as fruits and vegetables, as well as to prevent biodiversity losses and protect the environment by avoiding the use of today's forests, woodlands, pastures, rangelands and mountain sides for agriculture. Furthermore, recent research shows that investment in crop yield gains compares favorably with other commonly proposed climate change mitigation strategies, and should be a priority target to reduce greenhouse gas emissions. 
Identifying the most appropriate technologies and practices to achieve these objectives are critical. This requires the building of a knowledge base to support such tasks. Fortunately, the World already possesses the know-how and research capability required to achieve the main objective to transform agriculture into a fully natural resource-based system which manages eco-efficiently its surrounding environment and associated biodiversity. Agro-ecological approaches are known to improve farming system productivity, reduce pollution through sound methods of nutrient and pest management, maintain biodiversity reserves, and enhance habitat quality through careful management of soil, water, and natural vegetation. Infrastructure (particularly roads and irrigation), incentives, institutions and other innovations beyond agriculture are also needed to implement such a global change of rural landscapes in the short- to mid-terms. The agenda for a new "Green Revolution” needs to consider new approaches to promote innovations in plant science, agricultural and management practices and benefits to farmers and consumers.

Modern production agriculture in the developed world is highly industrialized. There is considerable discussion about the inadequacy of the dominant model of agricultural intensification and growth, which relies on increased use of capital inputs, such as fertilizer and pesticides [43]. Technology and purchased inputs, e.g. fertilizer, pesticides and water are required to maintain high levels of production, and use of these inputs continues to increase in the developing world. Despite the critical need for agricultural production and continued improvements in management practices, current systems are still not in "harmony" with the environment because they can create many problems for ecosystems and human communities. The generation of unacceptable levels of environmental damage and problems of economic feasibility are cited as key problems with this model of industrial agriculture [45] [46]. Specific external costs of industrial agriculture which should be improved include soil deterioration, erosion, declining surface water and groundwater quality, limited recycling of nutrients, excessive use of off-farm fertilizers and pesticides, diminished biodiversity within the agricultural system (both in terms of the variety of crops sown and coexisting species), lapses in food safety, and the loss of rural employment. By developing new field crops, and trees that meet societal needs, plant breeding plays a distinctive and crucial role in addressing these challenges, which must be dealt with immediately to develop sustainable agronomic systems for the future.

In this article two general ways are described in which plant breeders can engage in environmental issues: 1) by breeding plants that are better adapted to environment and environmental stresses, producing more with less and where productivity can be maintained in the face of increasingly variable weather patterns and sub-optimal conditions, as well as pest and disease pressures; and 2) by breeding plants that can alter and "improve" environments, as breeding alternative crops and crops for new uses or breeding for local adaptation and sustainable solutions. It is also presented the impacts of transgenic crops, commonly referred to as genetically modified crops on biodiversity.

\section{Plant Breeding, Agriculture and Environment}

\subsection{Introduction}

Farming and plant breeding have been closely associated since the early days when crops were first domesticated. The domestication of staple crops, for example, rice and soybean in eastern Asia; wheat in the Middle East; sorghum in Africa; and maize, beans, and potatoes in the Americas [47], began independently, in multiple locales, 5000 - 12,000 years ago [47]. For thousands of years, these crops were grown and morphologically altered by farmers, who selected the most desirable and adaptable cultivars to plant in the next growing season. Without understanding the science behind it, early farmers saved the seed from the best portion of their crop each season. Over the years, they selected the traits which they liked best, transforming and domesticating the crops they grew.

After the discoveries of Darwin and Mendel, scientific knowledge was applied to plant breeding in the late 1800s [40]. Commercial hybridization of crop species began in the United States in the middle of the 1920s with sweet corn and followed by onions in the 1940s [4]. With the implementation of hybrid crop breeding, yield per unit land area rapidly increased in the United States [48] and since that time, public and private breeding companies have been placing more and more emphasis on the development of hybrids, and many species have been bred as hybrid cultivars for the marketplace. Besides heterosis, hybrids also allow breeders to combine the best traits and multiple disease and stress resistances. Furthermore, if the parents are homozygous, the hybrids will be uniform, an increasingly important trait in commercial market production. The creation of hybrid cultivars re- 
quires homozygous inbred parental lines, which provide a natural protection of plant breeders' rights without legal recourse and ensure a market for seed companies.

In the 1970's breeders' rights protection has been provided through International Union for the Protection of New Varieties of Plants (UPOV), which coordinates an international common legal regime for plant variety protection. Protection was granted for those who develop or discover cultivars that are new, distinct, uniform, and stable [49]. Cultivars may be either sexually or asexually propagated. Coverage for herbaceous species is 20 years. Protective ownership was extended by UPOV in 1991 to include essentially derived cultivars [49]. At the same time, the farmer's exemption (which permitted farmers to save seed for their own use) was restricted; giving member states the option to allow farmers to save seed. Additionally, in Europe after 1998 and the United States after 2001, plant breeding companies can take advantages of patent laws to protect not only the cultivar itself but all of the plant's parts (pollen, seeds), the progeny of the cultivar, the genes or genetic sequences involved, and the method by which the cultivar was developed [50]. The seed can only be used for research that does not include development of a commercial product i.e., another cultivar, unless licensed by the older patent. The patents are considered the ultimate protective device allowing neither a farmer's exemption nor a breeder's exemption (that permitted the protected cultivar to be used by others in further breeding to create new cultivars) [51]. The use of patents for transgenic crops introduces additional problems according to the IAASTD report [46] developed with the contribution from 400 scientists around the world, and adopted by 58 governments. In developing countries, especially instruments such as patents may boost up costs and restrict experimentation by individual farmers whereas potentially undermining local practices for securing food and economic sustainability. Thus, there is particular concern regarding present intellectual property rights instruments, which may inhibit seed-saving, exchange, sale, and access to proprietary materials of vital importance to the independent research community, specifically in view of the need for analyses and long term experimentation on climate change impacts [49] [50].

Research and development (hereafter R \& D) for improved seed development is expensive. Such product protection has presented a business incentive to corporations to invest in the seed industry, which supported an enormous increase in private R \& D leading to strong competition in the marketplace between the major seed companies. The majority of current crop cultivars sold nowadays are proprietary products developed by private $\mathrm{R} \& \mathrm{D}$. A significant consequence of this increase in $\mathrm{R} \& \mathrm{D}$ has been a reduction in public breeding programs. As a result, the cost for R \& D to develop new crop cultivars is shifting from the publicly supported research programs to the customers of the major seed companies [4] [52].

One of the main factors to determine success in plant breeding is crop biodiversity and genetic capacity. Access to genetic variation, biodiversity, is required to achieve crop cultivar improvement. No practical breeding program can succeed without large numbers of lines (genotypes) to evaluate, select, recombine and inbreed (fix genetically). This effort must be organized in order for valid conclusions to be reached and decisions to be made. Scientists, breeders, support people and facilities, budgets, and good management are requirements to assure success in the seed business. Science must be state-of-the-art to maximize success in a competitive business environment. The continued need for fundamental breeding research is critical to support development of new technology and expansion of the knowledge base which supports cultivar development, competition among proprietary cultivar results in owner-companies striving to do the best possible research to develop their own products and to compete on genetic and physiological quality of crop seed in the marketplace. Reasonable profit margins are essential to pay back the R \& D costs to the owner and to fund future research on developing even better crop cultivars to stay competitive. There is considerable genetic variation within the numerous crop species, which can be exploited in the development of superior proprietary cultivars. The consequences of this dynamic situation will mean relatively short-lived cultivars replaced by either the owner of the cultivar or a competitor seed company. This intense competition means constantly improved and more sophisticated cultivars. Seed companies are in the business of manipulating genes to improve plant cultivar performance for a profit. The success of the research is judged by the success of the product in making a reasonable profit. The research must improve economic performance starting with the seed production costs and including the farmer-shipper/processor and the end user. If any link in this sequence of events is weak or broken, the new cultivar will likely fail [4] [53].

Modern plant breeding is the science of improving plants to achieve farmer needs and better fit production environments, but it is a long-term proposition. Each released cultivar represents a culmination of a decade or more of work, from initial crosses through final testing. The rate of improvement is a function of the amount of 
heritable genetic variation present in a population, the time it takes to complete a breeding cycle (from seed production through selection to seed production again), which can range from multiple generations per year (e.g. maize on field sites in both hemispheres) to decades (some trees require 8 years of growth before flowering). In hybrid crops, several years (multiple breeding cycles) are necessary to develop inbred lines that must then be tested in hybrid combinations. Many years of testing under various environmental conditions must be conducted to ensure that the new cultivar (inbred, hybrid, or population) will perform well for the farmer, consumer, or end-user before any substantial additional investment is made to increase production and distribution of the cultivar.

Biotechnology is a new and potentially powerful tool that has been added by all the major seed corporations to their crop breeding research programs, and is part of an ongoing public research for developing genetic engineered crop projects. It can augment and/or accelerate conventional cultivar development programs through time saved, better products, and more genetic uniformity, or achieve results not possible by conventional breeding [54]. Genetic engineering provides innovative methods for modern plant breeding to adapt crops to agricultural systems facing new challenges brought by the changing climate. New breeding methods, relying on genetic engineering, can accelerate the pace to improve crops, or be more precise in transferring desired genes into plant germplasm. Some limited target traits already available in transgenic cultivars include those adapting agriculture to climate change and reducing their emissions of greenhouse gases.

Plant breeding may benefit from recent advances in genotyping and precise phenotyping, and by increasing the available agro-biodiversity through the use of genomics-led approaches. Today marker-assisted breeding is applied to a broad range of crops and could facilitate domesticating entirely new crops. Marker-assisted selection is particularly important for improving complex, quantitatively inherited traits that alter yield, and for speeding up the breeding process [55]. Crop genomics has also been improving in the last decade and today there are faster and cheaper systems being increasingly used in gene banks, genetic research and plant breeding, e.g. for studying interactions between loci and alleles such as heterosis, epistasis and pleiotropy, or analyzing genetic pathways. Advances in crop genomics are providing useful data and information for identifying DNA markers, which can be further used for both germplasm characterization and marker-assisted breeding. Genomics-assisted breeding approaches along with bioinformatics capacity and metabolomics resources are becoming essential components of crop improvement programs worldwide [49] [56].

Progress in crop genome sequencing, high resolution genetic mapping and precise phenotyping will accelerate the discovery of functional alleles and allelic variation associated with traits of interest for plant breeding. Genome sequencing and annotation include an increasing range of species such as banana/plantain, cassava, citrus, grape, model legumes, maize, potato, rice, sorghum, sugarcane, soybean, among other species. Perhaps, one day further research on the genome of a plant species from a drought-prone environment may assist in breeding more hardy and water efficient related crops due to gene synteny.

Transgenic breeding involves the introduction of foreign DNA. The use of transgenic crops remains controversial worldwide after more than 1.5 decades of introducing them into the agro-ecosystems using specific frameworks to regulate their release and commercialization. While conventional plant breeding utilizing nontransgenic approaches will remain the backbone of crop improvement strategies, transgenic crop cultivars should not be excluded as products capable of contributing to development goals. Breeding of transgenic crops so far seems to have been responsible and regulatory agencies have proceeded with caution in releasing transgenic crops. Available commercial transgenic crops and products are at least as safe in terms of food safety as those ensuing from conventional plant breeding [54] [57]-[59]. Farm level profitability will ultimately determine whether farmers adopt and retain new transgenic crop technology, which may also depend on much more than technical performance particularly in the developing world; e.g. national research capacity, environmental and food safety regulations, intellectual property rights and agricultural input markets.

Decisions, policies and procedures about monitoring transgenic crops should be science-based, and this approach requires education. There will be continuing assessment on the need for, and type of monitoring as new (and unique) products are developed and released to agro-ecosystems. For example, when deploying transgenic crops with host plant resistance to an insect pest (e.g. expressing Cry insecticidal proteins derived from Bacillus thurigiensis) numerous experiments are conducted to determine effective insect resistance management strategies for farmers. Collecting baseline data is indeed essential for effective monitoring and guiding research on transgenic crops. Environmental, food and feed safety aspects should also be investigated before releasing transgenic crops. Another research area should focus on the unintentional spread of transgenic traits into convention- 
ally-bred crop or landrace gene pools of the same species, particularly in the centers of crop diversity or origin. Transgene flow raises a new set of ecological and economic issues for scientists and policymakers to consider for transgene containment. Appropriate measurements should also be taken when transgenic and conventional crops of the same species coexist in the same locations if some farmers wish to grow crops for transgenic-free markets. The global spread of transgenic crops also has significant implications for organizations involved in germplasm conservation and genetic enhancement. Protocols, which are most likely based on polymerase chain reaction (PCR) markers for detecting specific recombinant DNA sequences in bulked samples collected from sentinel plots, are therefore needed to monitor unintentional transgene flow in gene banks and breeding plots. Using plant-derived genes to introduce useful traits and plant-derived promoters, will also overcome some concerns about the development of genetically engineered crops. In this regard, cisgenesis addresses some negative views regarding the use of genes from non-crossable species for breeding crops. Cisgenesis involves only genes from the plant itself or from a crossable close relative, and these genes could also be transferred by conventional breeding methods. Crop wild relatives are therefore a valuable source of traits for cisgenesis. The impact of transgenic crops on biodiversity is discussed in chapter 3 .

Plant breeders need to understand the various valuation strategies very early in the breeding process if they are to direct long-term selection toward reducing agriculture's negative environmental impacts and achieving greater sustainability while maintaining productivity. Regardless of method, breeding objectives can be broadened to include traits which reduce the environmental footprint of traditional production systems (e.g. nutrient and water use efficiencies that reduce off-farm inputs), to adapt crops to new climates, to host plant resistance to tackle old and emerging pathogen epidemics, or new cultivars for new production systems (e.g. perennial polycultures that mimic the biodiversity of natural systems), albeit with some reduction in rate of gain for the traditional agronomic traits of interest. Interdisciplinary crop improvement strategies accounting for ecological, socio-economic and stakeholder considerations will help identify traits leading to plant cultivars using fewer inputs, less land, and less energy, thereby resulting in a more sustainable agricultural ecosystem.

The impact of breeding on crop production is dependent upon the complex relationships involving the farmers, the cultivars available to them, and the developers of those cultivars. Farmers consist of commercial producers with varying size land holdings ranging from moderately small farms to very large ones, and subsistence farmers with small farms often on marginal lands. The subsistence farmers are usually poor. Several types of cultivars are available. The least sophisticated in terms of methods of development are landraces, also known as local cultivars. Modern cultivars consist of development by crossing and selection alone, those developed by crossing and selection with specific important improvements are often obtained from crosses with wild species or by transgenic methods, and $F_{1}$ hybrids between desirable inbred lines. The developers of landraces are usually farmers themselves, and are obtained by repeated simple selection procedures of generation after generation. Improved cultivars and hybrids are created either by public sector breeders or seed companies.

Nearly $70 \%$ of the world's farmers, from 570 million world exploitations, are small/subsistence and poor farmers. They feed 1.5 billion of the world's population. So they are also a key for biodiversity and for improving the sustainability. For these farmers improved cultivars, hybrids or transgenic seeds tend to be riskier than landraces, since the higher costs associated with seeds and production impose a greater income risk. The lack of capital available denies them the opportunity to invest in production inputs. Small farmers may have lower production costs with landraces because they achieve adequate yields with fewer inputs. In addition, profits from improved hybrid or transgenic cultivars tend to be more variable. Yields are often higher but market prices tend to be inconsistent. For example in India states of Andhra Pradesh and Maharashtra, farmers have been promised higher yields and lower pesticide costs when using $B t$ cotton, thus they acquired loans to afford the costly seeds (Monsanto has control over 95\% of the Indian Bt cotton seed market and this near monopoly has resulted in great increased prices). When, in many cases, the farmers found the yields failed to meet their expected result, the consequences were usually very serious and many farmers died by committing suicide over the past 15 years, perhaps due to this reason. This situation of using $B t$ cotton seeds was explained by the absence of irrigation systems combined with specialization in high-cost crops, and played low market prices. Without collateral help these farmers are usually unable to secure a loan from a bank or money lender [53] [60]. Rates are often unmanageably high for those able to get a loan, with strict penalties for late payments. Similarly, a lack of education, resources, skill training and support prevent these farmers from using improved cultivars and then to generate a stable income from their production. In addition, governments do not usually regulate the price of crops or even provide market information. Improving market information systems for crops and facilitating farmers' 
access to credit are then essential components for a strategy to enable poor farmers to grow improved cultivars. A major obstacle to success in crop production using improved cultivars is the shortage of affordable credit. Desperate for cash, subsistence farmers are forced to sell their crops immediately after the harvest to middlemen or their creditors at unfavorable prices. Low cost quality seeds are essential for these poor farmers to improve their life [60].

\subsection{Breeding to Adapt Plants to the Environment}

\subsubsection{Producing More with Less}

In the coming decades we will need to produce more with less. Fresh water suitable for irrigation is expected to become increasingly scarce and the costs of fertilizer and other agricultural inputs will increase as fossil-fuel costs rise. Nevertheless, continuing gains in production per hectare must be realized to offset the loss of premium agricultural lands (e.g. from urbanization and industrialization), while supplying a growing population. By developing resource efficient plants, plant breeders can continue to improve the sustainability of agricultural ecosystems. Plants requiring fewer off-farm input applications (specifically water, pesticides, nitrogen, phosphorus, and other nutrients) decrease the cost of production, lower fossil energy use, and reduce contamination of water systems, which help to improve public health and stabilize rural economies [61] [62].

Although modern plant breeding efforts initially focused on improving uptake of inputs, recent efficiency gains have been made in physiologically increasing yield and biomass production without further increasing inputs. Many crops already have genetic variation in nutrient use efficiency, utilization, and uptake [63]-[65] and plant breeding will further improve these traits. Intensive agro-ecosystems, central to food security and reducing rural poverty, should emphasize improvements in system productivity, host plant resistance and enhance useefficiency of inputs such as water and fertilizers.

Water use-efficiency and water productivity are therefore being sought by agricultural researchers worldwide to address water scarcity in drought-prone environments across the world. Under water scarcity, yields, of some crops, are a function of the amount of water used by the crop, how efficiently the crop uses this water for biomass-growth (i.e., water use efficiency or above-ground biomass/water use), and the harvest index; i.e., the proportion of grain yield to above-ground biomass. Water use efficiency is the ratio of total dry matter accumulation to evapotranspiration and other water losses; i.e., water entering and being lost from the system which is not transpired through the plant. An increase in transpiration efficiency or reduction in soil evaporation will increase water use efficiency. More recently, water productivity was re-defined at the crop level as the ratio of biomass with economic value produced (for example grain yield of cereals) compared to the amount of water transpired. This water productivity has been labeled as "productive" because transpiration is the only water flow in a field actually passing through the crop. Both water use efficiency and water productivity may be improved through plant breeding, as biomass accumulation and harvest index. Farooq et al. [66] discuss the advances in transgenic breeding for drought-prone environments. In their review, they noted the testing of 10 transgenic rice events [unique DNA recombination taking place in one plant cell and thereafter to be used for generating entire transgenic plant(s)] under water scarcity. It seems the transgenic expression of some stress-regulated genes leads to increased water use efficiency.

Agriculture contributes significantly to greenhouse gas emissions. Nitrous oxide and dioxide are potent greenhouse gases released by manure or nitrogen $(\mathrm{N})$ fertilizer, particularly in intensive cropping systems. Nitrous oxide $\left(\mathrm{N}_{2} \mathrm{O}\right)$, which is a potent greenhouse gas susceptible to denitrification, is generated through use of manure or $\mathrm{N}$ fertilizer. In many intensive cropping systems common $\mathrm{N}$ fertilizer practices lead to high fluxes of $\mathrm{N}_{2} \mathrm{O}$ and nitric oxide (NO). Several groups of heterotrophic bacteria use $\mathrm{NO}_{3}$ as a source of energy by converting it to the gaseous forms $\mathrm{N}_{2}, \mathrm{NO}$, and $\mathrm{NO}_{2}$ (nitrous dioxide). $\mathrm{N}_{2} \mathrm{O}$ is therefore often unavailable for crop uptake or utilization. Proper amounts and timing of $\mathrm{N}$ applications can reduce $\mathrm{NO}_{2}$ emissions (50\% less) in intensive irrigated agro-ecosystems without significantly affecting crop yields. An optical, hand held sensor which calculates the normalized differential vegetative index, thereby assessing yield potential as plants grow, can reduce unneeded $\mathrm{N}$ fertilizer inputs, saving farmers' money and protecting the environment by reducing trace gas emissions. Genetic enhancement of crops shows great potential for reducing $\mathrm{N}_{2} \mathrm{O}$ emissions from soils into the atmosphere. Some plants possess the capacity to modify nitrification in situ because they produce chemicals which inhibit nitrification in soil. This release of chemical compounds from plant roots suppressing soil nitrification has been called biological nitrification inhibition, which seems to vary widely among and within species, 
and appears to be a widespread phenomenon in some tropical pasture grasses, e.g. Brachiaria humidicola. Nitrification inhibition also enhances agro-ecosystem fertility in a sustainable way especially under high nitrate leaching and denitrification fluxes, which may account for the ecological advantage of African grasses over indigenous grasses of other tropical pastures. Biological nitrification inhibition may be an interesting target trait of crop genetic engineering for mitigating climate change.

Almost one-fifth of global methane emissions are from enteric fermentation in ruminant animals. Apart from various rumen manipulation and emission control strategies, genetic engineering is a promising tool to reduce these emissions. The amount of methane produced varies substantially across individual animals of the same ruminant species. Efforts are ongoing to develop low methane-emitting ruminants without impacting reproductive capacity and wool and meat quality. A recent study by Shi et al. [67], to understand why some sheep produce less methane than others, deployed high-throughput DNA sequencing and specialized analysis techniques to explore the contents of the rumens of sheep. The study showed that the microbiota present in sheep rumen was solely responsible for the differences among high and low methane emitting sheep. It was further observed that the expression levels of genes involved in methane production varied more substantially across sheep, suggesting differential gene regulation. There is an exciting prospect that low-methane traits can be slowly introduced into sheep.

Crops are bred for $\mathrm{N}$ use efficiency (hereafter NUE) because this trait is a key factor for reducing $\mathrm{N}$ fertilizer pollution, improving yields in $\mathrm{N}$ limited environments, and reducing fertilizer costs. The use of plant species or genotypes of same species efficient in absorption and utilization of $\mathrm{N}$ is an important strategy in improving NUE in sustainable agricultural systems. Whole plant physiology, quantitative genetics, and forward and reverse genetic approaches are providing a better understanding of the physiological and molecular controls of $\mathrm{N}$ assimilation in crops under varying environments. Crops are being bred for NUE because this trait will be a key factor for reducing $\mathrm{N}$ fertilizer pollution as well as for improving yields in $\mathrm{N}$ limiting environments. There are various genetic engineering activities for improving NUE in crops [64] [68]. The gene Alanine aminotransferase from barley, which catalyzes a reversible transamination reaction in the $\mathrm{N}$ assimilation pathway, seems to be a promising candidate for accomplishing this plant breeding target. Transgenic plants over-expressing this enzyme can increase $\mathrm{N}$ uptake especially at early stages of growth. This gene technology was licensed to a private biotechnology company, which was founded in the last decade with the aim of promoting sustainable agriculture by running a profitable company [69]. A patent issued a few years ago gave this company the rights to use the NUE gene technology in major cereals (wheat, rice, maize, sorghum, and barley), as well as, in sugarcane. Today they are testing the technology with rice in China, and researching further with rice and wheat in India, and planning to assess its value for maize and rice in sub-Saharan Africa through private-public partnerships.

Keeping $\mathrm{N}$ in ammonium form will affect how $\mathrm{N}$ remains available for crop uptake and will improve $\mathrm{N}$ recovery, thus reducing losses of $\mathrm{N}$ to streams, groundwater and the atmosphere. There are genes in tropical grasses such as B. humidicola and in the wheat wild relative Leymus racemosus that inhibit or reduce soil nitrification by releasing inhibitory compounds from roots and suppressing Nitrosomonas bacteria [70]. Their value for genetic engineering crops for reducing nitrification needs to be further investigated.

\subsubsection{Adapting to Global Climate Change and for Abiotic and Biotic Stress Tolerance}

Extreme weather events are expected to increase in both number and severity in coming years [71]. Climate change impacts agro-ecosystems through changes over the long-term in key variables affecting plant growth (e.g. rising temperatures) and through increasing the variability (frequency and intensity) of weather conditions (rainfall, drought, waterlogging and elevated temperatures). These changes affect both crop productivity and quality. In addition to physically destroying crops, climate change has altered host-pathogen relationships and resulted in increased disease incidence, in insect-pest borne stress in crop plants, and in invasive pests which feed and damage them.

There are two ways to adapt crops to new environments: developing new crops (long-term endeavor starting with domestication) and introducing target traits into existing crops through plant breeding, which includes genetic engineering. However, the job of crop improvement is becoming increasingly difficult. Cultivars which are not only high yielding but are also efficient in use of inputs are needed, tailored to ever more stringent market demands, able to maintain stability under increasing climate variability, and potentially contribute to climate mitigation. These multi-trait demands for new cultivars provide significant challenges for crop breeders, and standard selection approaches struggle under such complexity. To maintain productivity in the face of increased 
climatic variability, both the population and the plant cultivars will need to be continually developed to withstand "new" climate extremes and the stresses which these will entail [72].

Many breeding programs are already developing plants which tolerate extreme weather conditions, including drought, heat, and frost [73] [74]. Plant breeders are also beginning to address expected changes due to increased climate variability, by increasing genetic diversity sources and by adjusting selection and testing procedures [75].

More frequent weather extremes will likely affect the existing ranges of not only agronomic cultivars but also local native plant species [76]. Because some genetic variation useful for climate change adaptation will be found only in wild plant relatives of cultivated crops, preserving genetic biodiversity is essential in order for breeders to select plants that will be well-suited for future environmental conditions [77].

Global climate change notwithstanding, additional stress tolerances in crop species are needed to maintain productivity and survival. In the near future, tolerance to various soil conditions including acidic, aluminum-rich soils (particularly in the tropics) and saline soils (especially those resulting from irrigation), will be increasingly important for production on marginal agricultural lands or as the salt content of irrigated lands increases [78]. Bhatnagar-Mathur et al. [79] suggested that genetic engineering could accelerate plant breeding to adapt crops to stressful environments. They further underline that engineering the regulatory machinery involving transcription factors (TF; a protein binding specific DNA sequences and thereby governing the flow of genetic information from DNA to messenger RNA) provides the means to control the expression of many stress-responsive genes. There are various target traits for adapting crops, through genetic engineering, to high $\mathrm{CO}_{2}$ and high $\mathrm{O}_{3}$ environments of the changing climate [80]. Ortiz [81], Jewell et al. [82], and Dwivedi et al. [83] [84] provide the most recent overviews on research advances in genetic engineering for improved adaptation to drought, salinity or extreme temperatures in crops. The most cited include TF, and genes involved in: 1) signal sensing, perception, and transduction; 2) stress-responsive mechanisms for adaptation; and 3) abscisic acid biosynthesis for enhanced adaptation to drought. Transporter, detoxifying and signal transduction genes as well as TF are cited for tolerance to salinity. Genes related to reactive oxygen species, membrane and chaperoning modifications, late abundance embryogenesis proteins, osmoprotectants/compatible solutes and TF are pursued in crop genetic engineering for temperature extremes.

Transgenic crops provide the means to adapt crops to climate change, particularly in terms of drought and salinity. Duration and intensity of drought has increased in recent years, consistent with expected changes of the hydrologic cycle under global warming. Drought dramatically reduces crop yields. Genetic engineering may be one of the biotechnology tools for developing crop cultivars with enhanced adaptation to drought [85]. It should be seen as complementary to conventional plant breeding rather than as an alternative to it. The function of a TF such as the Dehydration-Responsive Element Binding (DREB) gene in water stress-responsive gene expression has been extensively investigated [86]. The main research goal was to gain a deep understanding of TF in developing transgenic crops targeting drought-prone environments [87]. For example, the DREB1A gene was placed under the control of a stress-inducible promoter from the $r d 29 \mathrm{~A}$ gene and inserted via biolistic transformation into wheat bread [88]. Plants expressing this transgene demonstrated significant adaptation to water stress when compared to controls under experimental greenhouse conditions as manifested by a 10-day delay in wilting when water was held. Saint Pierre et al. [89] indicated, however, that these transgenic lines did not generally out-yield the controls under water deficit in confined field trials. Nonetheless, they were able to identify wheat lines combining acceptable or high yield under enough irrigation which also showed stable performance across the water deficit treatments used in their experiments; i.e., severe stress, stress starting at anthesis, and terminal stress.

Soils affected by salinity are found in more than 100 countries, and about $1 / 5$ of irrigated agriculture is adversely affected by soil salinity. Therefore, breeding salt-tolerant crops should be a priority because salinity will most likely increase under climate change. Mumms [90] lists some candidate genes for salinity tolerance, indicating the putative functions of these genes in the specific tissues in which they may operate. Genes involved in tolerance to salinity in plants, limit the rate of salt uptake from the soil and the transport of salt throughout the plant, adjust the ionic and osmotic balance of cells in roots and shoots, and regulate leaf development and the onset of plant senescence. The most promising genes for the genetic engineering of salinity tolerance in crops, as noted by Chinnusamy et al. [91], are those related to ion transporters and their regulators, as well as the C-repeat-binding factor. The recent genome sequencing of Thellungiella salsuginea, a close relative of Arabidopsis thriving in salty soils, will provide more resources and evidence about the nature of defense mechanisms consti- 
tuting the genetic basis underlying salt tolerance in plants [92].

In the quest for breeding transgenic rice and tomato, advances showing salt tolerance have occurred. Plett et $a l$. [93] were able to show an improved salinity tolerance in rice by targeting changes in mineral transport. They initially observed that cell type-specific expression of AtHKT1 (a sodium transporter) improved sodium $\left(\mathrm{Na}^{+}\right)$ exclusion and salinity tolerance in Arabidopsis. Further research explored the GAL4-GFP enhancer trap (transgenic construction inserted in a chromosome and used for identifying tissue-specific enhancers in the genome) to drive expression of AtHKT1 in the root cortex in transgenic rice plants. The transgenic rice plants had a higher fresh weight under salinity stress due to a lower concentration of $\mathrm{Na}^{+}$in the shoots. They also noted that root-toshoot transport of ${ }^{22} \mathrm{Na}^{+}$decreased and was correlated with an up-regulation of OsHKT1, the native transporter responsible for $\mathrm{Na}^{+}$retrieval from the transpiration stream. Moghaieb et al. [94] bred transgenic tomato plants producing ectoine (a common compatible solute in bacteria living in high salt concentrations). Ectoine synthesis was promoted in the roots of transgenic tomato plants under saline conditions, which led to increased concentration of photosynthesis in improving water uptake. Likewise, the photosynthetic rate of ectoine-transgenic tomato plants increased through enhancing cell membrane stability in oxidative conditions under salt stress.

Transgenic crops can also contribute to climate change mitigation efforts by reducing input use intensity [95]. The integration of genetic engineering with conventional plant breeding, within an interdisciplinary approach, will likely accelerate the development and adoption of crop cultivars with enhanced adaptation to climate change related stresses [96]. Global warming will reduce yields in many crops about $6 \%$ and $5 \%$ average yield loss per $1^{\circ} \mathrm{C}$ in $\mathrm{C}_{3}$ and $\mathrm{C}_{4}$ crops, respectively, whose optimum temperature ranges are $15^{\circ} \mathrm{C}-20^{\circ} \mathrm{C}$ and $25^{\circ} \mathrm{C}$ $30^{\circ} \mathrm{C}$ [97]. The extent of yield loss depends on crop, cultivar, planting date, agronomy and growing area. For instance, an increase of $1^{\circ} \mathrm{C}$ in the night time maximum temperature translates into a $10 \%$ decrease in grain yield of rice, whereas a rise of $1^{\circ} \mathrm{C}$ above $25^{\circ} \mathrm{C}$ shortens the reproductive phase and the grain-filling duration in wheat by at least $5 \%$, thereby reducing grain yield proportionally. Heat stress will exacerbate climate change impacts in the tropics, while it may put agriculture at risk in high latitudes where heat-sensitive cultivars are grown today. Hence, new cultivars must be bred to address heat stress. Ainsworth and Ort [98] suggested giving priority to traits improving photosynthesis for adapting to heat stress. However, plants have various mechanisms to cope with high temperatures, e.g. by maintaining membrane stability, or by ion transporters, proteins, osmoprotectants, antioxidants, and other factors involved in signaling cascades and transcriptional control [99] [100]. Furthermore, Gao et al. [101] noted that bZIP28 gene (a gene encoding a membrane-tethered TF) up-regulated in response to heat in Arabidopsis. Some of these genes can be used in crop genetic engineering to enhance plant adaptation to heat stress. For example, some stress-associated genes such as ROB5, a stress inducible gene isolated from bromegrass, enhanced performance of transgenic canola and potato at high temperatures [102]. Likewise, Katiyar-Agarwal et al. [103] introduced hsp101 gene (a heat shock protein gene from Arabidopsis) in basmati rice. This transgenic rice had a better growth in the recovery phase after suffering heat stress.

Globalization has, among other consequences, led to the rapid spread of plant disease and invasive pests. Being immobile, plants are unable to escape pathogens causing plant disease and pests which feed and damage them. Plant disease is mainly caused by fungi, bacteria, viruses, and nematodes. Approximately 70,000 species of pests exist in the world, but of these, only $10 \%$ are considered serious [104]. Synthetic pesticides have been applied to crops since 1945 and have been highly successful in reducing crop losses to some pest insects, plant pathogens, weeds and in increasing crop yields [104]. One estimate suggests that without pesticides, crop losses to pests might increase by $30 \%$. Despite pesticide use, insects, pathogens and weeds continue to exact a heavy toll on world crop production, approaching 40\% [104] [105]. Pre-harvest losses are globally estimated at $15 \%$ for insect pests, $13 \%$ for damage by pathogens, and about $12 \%$ for weeds [104]. Developing resistant cultivars reduces the need for expensive and environmentally damaging pesticides to be applied. For example, a recent outbreak of Xanthomonas campestris pv. musacearum led to the devastating Xanthomonas wilt of banana in the Great Lakes Region of Africa, thereby threatening the food security and income of millions of East and Central African people who depend on this crop. Transgenic banana plants with the hypersensitivity response-assisting protein (Hrap) gene from sweet pepper did not show any infection symptoms after artificial inoculation of potted plants with Xanthomonas wilt in the screen house [106]. Selected transgenic banana plants with putative host plant resistance to Xanthomonas wilt are ongoing confined field-testing in East Africa, where elevated temperatures, due to the changing climate, will likely favor banana production.

Weather influences how pathogens and pests affect and interact with crops and their host plant resistance, and thus climate change can also have wide-ranging impacts on pests and diseases [84]. Late blight, which is caused 
by Phytophthora infestans, ranks as the most damaging potato pest. Late blight accounts for $20 \%$ of potato harvest failures worldwide, translating into 14 million tonnes valued at 7.6 billion US dollars. Global warming will increase late blight spread, e.g. expanding its range above 3000 meters in the Andes [107]. Chemical control may lead to more aggressive strains of the pathogen and chemical control is often regarded as being environmentally damaging. Cisgenic potato cultivars with late blight resistance are becoming available and will impact growers, consumers and the environment favorably [108]. Related wild Solanum species can be a source of alleles to enhance host plant late blight resistance in potato. For example, S. bulbocastum (a wild relative with high resistance to late blight from Mexico) was used to breed the cultivar "Fortuna" using genetic engineering. Cisgenesis allows inserting several host plant resistance genes from wild crop species in one step without linkage drag (reduction in cultivar fitness).

\subsection{Breeding Plants to Improve the Environment}

In general, plants are bred for their most obvious end products, including grain, fiber, sugar, biomass yield, fruit quality, or ornamental qualities. However, plants deployed across the landscape in agricultural or forestry settings affect the environment in measurable ways. Perennial crops have environmentally beneficial properties not present in annual crops, such as helping to prevent erosion in agricultural systems, providing wildlife habitat, and acting as sinks for carbon and nutrients. Traditionally, perennial crops have not been a major focus of breeding programs because they generally take more time and scientific knowledge to improve, and therefore, products such as new cultivars are often not produced within the timeframe of funding cycles. Current tree breeding programs are developing elms (Ulmus spp.), chestnuts (Castanea dentata), hemlocks (Tsuga spp.), and other species which are resistant to introduced diseases and insects [109] [110]. As compared with natural selection, artificial selection via plant breeding has overcome these stresses more effectively by rapidly incorporating diverse exotic genetic sources of resistance, hybridizing to include multiple, different genetic resistances into the same plant, and making use of off-season locations or artificial conditions to shorten generation cycles. A more complex example which may be feasible in the future is tree breeding for larger and improved root systems to decrease soil erosion, sequester carbon, and improve soil quality by increasing soil organic matter.

New crop cultivars developed by plant breeders must help improve soil health, reduce soil erosion, prevent nutrient and chemical runoff, and maintain biodiversity. The goal to breed projects for forages, which include several species, is to produce a high yield of leaf and stem biomass, as opposed to grain, for ruminant animals. In the tropics many forages are perennial, providing year-round erosion control, improving water infiltration as compared with that, from annual cropping systems, and in some cases, sequestering carbon. The forage breeding program at the University of Georgia (UG) has developed cultivars in several species and has been proactive in developing agreements with private-sector commercial partners to oversee seed production and marketing of new cultivars. Among the cultivars developed at UG is "Jesup MaxQ" tall fescue, a cultivar carrying a non-toxic endophytic fungus that was both highly persistent under grazing and greatly improved animal weight gain and feed efficiency over standard cultivars. In addition, this program developed the first true dual purpose, grazing and hay, alfalfa cultivar "Alfagraze", followed by several further improved alfalfa cultivars like "Buldog 805" which persist through summer under cattle grazing [111].

Cover crops are annual species planted in rotation with crops to specifically improve soil conditions and to control weeds, soil-borne diseases, and pests [112]-[114]. Continuous cover crops can reduce on-farm erosion, nutrient leaching, and grain losses due to pest attacks and build soil organic matter as well as improve the water balance, leading to higher yields [115] [116]. For instance, Kaumbutho and Kienzle [117] showed that maize yield increased from 1.2 to 1.8 - 2.0 t/ha in Kenya with the use of a mucuna (velvet bean) cover crop using case studies conducted from 2004 to 2007; and Pretty and Hine [118] found that farmers who adopted mucuna cover cropping benefited from higher yields of maize with less labor input for weeding (maize following mucuna yields 3 - 4 t/ha without application of nitrogen fertilizer, similar to yields normally obtained with recommended levels of fertilization of $130 \mathrm{Kg} \cdot \mathrm{N} / \mathrm{ha}$ ).

Many current perennial and cover crop cultivars are essentially wild species bred from germplasm collections and developed to increase success in managed agro-ecosystems. As compared with non-native vegetation, plant species native to a particular region are generally thought to survive on less water, use fewer nutrients, require minimal pesticide applications, and be non-invasive; however, counter examples for both native and non-native species are plentiful [119]. As potentially valuable species are identified, breeding to improve them for traits of 
consumer importance will be needed to broaden available biodiversity in cultivated landscapes. With a changing climate, species considered critical to the landscape may require human-assisted hybridization with distant relatives to better ensure survival from threats posed by novel pests or diseases.

Alternative crops are also being bred for new uses, such as removing toxic chemicals and excess nutrients and improving degraded soils, including mine spoils [120]. Phytoremediation is a biotechnology to clean the contaminated sites of toxic elements (e.g. $\mathrm{Cd}, \mathrm{Cu}, \mathrm{Zn}, \mathrm{As}$, Se, Fe) via plant breeding, plant extracting, and plant volatilizing [121]. Phytoremediation of land contaminated with inorganic and/or organic pollutants has attracted much attention and research over the last decade [122]-[124]. Among the various approaches comprising phytoremediation, phytoextraction of metals and metalloids is probably the most challenging task. Where soils are impacted by industrial or mining activities, the degree of pollution is usually severe, making phytoextraction unfeasible within a reasonable time frame because of the high quantity of the pollutants present in the soil. Simple mass-balance calculations show that phytoextraction is potentially feasible only in low or moderately contaminated soils. For more heavily contaminated soils, phytostabilization with tolerant plants may be used to stabilize the contaminated sites and reduce the risk of erosion and leaching of pollutants to water bodies. Hyper-accumulation of metals or metalloids is important for the phytoextraction strategy [125] [126]. The last few years have seen a steady expansion in the list of hyper-accumulator species, which could be valuable plant resources for phytoremediation. A word of caution however, as the hyper-accumulation ability of some reported "hyper-accumulators" have yet to be confirmed in studies using field contaminated soils. Chaney et al. [125] discussed situations where phytoextraction may be applicable, such as paddy soils contaminated with moderate levels of cadmium (Cd) giving rise to Cd concentrations in rice grain exceeding the safe limit. An Indica-Japonica hybrid cultivar of rice was found to be an effective Cd phytoextractor, removing $7 \%-14 \%$ of soil Cd; this had the effect of decreasing subsequent Cd accumulation in soybean seeds in a pot study by $24 \%$ - $46 \%$ [127]. The efficient translocation of Cd from roots to shoots appears to be the main reason for the efficient Cd accumulation in this rice cultivar, although the underlying mechanisms remain unclear. A major QTL responsible for the root to shoot translocation of $\mathrm{Cd}$ has been identified in an $\mathrm{F}_{2}$ population constructed from the parental lines of rice differing in Cd accumulation in shoots by 13-fold [128]. While the trait for high Cd accumulation in shoots is useful for phytoextraction, the opposite is true for the strategy of breeding crops low in Cd accumulation for the benefit of food safety [129]. Many of the previous studies on phytoextraction have focused on hyper-accumulators. Small-scale field trials have shown that an ecotype of the $\mathrm{Zn} / \mathrm{Cd}$ hyper-accumulator Thlaspi caerulescens from southern France was able to phytoextract Cd efficiently through the different seasons with good growth of biomass [130] [131]. This ecotype possesses a high-affinity Cd uptake system which is not suppressed by Zn [132]. The Chinese brake fern Pteris vittata has a strong ability to hyper-accumulate arsenic (As) and shows promising potential for phytoextraction of and from contaminated soils under field conditions [133] [134], but the plant thrives only in the humid tropic/subtropical climates. Phytoextraction using high biomass plants such as willow (Salix sp.) and poplar (Populus sp.) has also been proposed [135]. Some Salix species are good accumulators of $\mathrm{Cd}$ and $\mathrm{Zn}$, and up to $20 \%$ of soil Cd was removed by cropping three S. asmithiana in a lysimeter study [136]. A large proportion of the metals are stored in leaves, so plants either have to be harvested before leaves fall or the fallen leaves are to be collected. Such biomass plants may be grown on contaminated areas not suitable for food production, allowing gradual phytoextraction of metals while the biomass may be used to generate energy by pyrolysis [137].

New perennial crops and tree species [e.g. switchgrass (Panicum virgatum), poplar (Populus spp.), Miscanthus, Arundo, etc.] are being developed as improved cellulosic feedstock for biofuels that will have a higher yield and energy content than was previously available [138] [139]. Cellulosic biofuels provide one approach for mitigating the impacts of global warming associated with fossil-fuel combustion, but concerns over appropriate implementation and environmental impacts remain [140]. Frontier approaches should be applied to study the possible advantages of perennial biofuel crops more photosynthetically productive, entail lower input costs, and improve soil nutrient input and retention. Through alliances with the bio-energy industry, research should also adapt industrial processes to biomass sources and sources to promising processes. Biofuels should form therefore part of a global, cross-cutting agenda of agricultural research, involving partners in the farming and energy sectors.

Simply developing more productive feedstock does not necessarily lead to enhanced environmental health. Without crop rotation, further monocultures of grain maize or increased palm oil production could have net negative environmental effects in the long term, but such efforts may be a necessary transition to facilitate infra- 
structure development for cellulosic feedstock. There is a concern however, that energy crops might inadvertently compete for land currently allocated for food crop production, and thereby raise food prices, must be considered carefully. Breeding alternative crops needs to be undertaken in close consultation with agronomists, economists, ecologists, and the commercial sector or industry, to ensure that new cultivars have the proper traits making them both profitable and sustainable.

The increasing demand, particularly by the industrialized world, for biofuels should take into account the agro-ecosystems and its biodiversity to ensure their healthy management. The agricultural systems required for producing biofuels need to be sustainable for an efficient use of biomass, and partitioning it among energy, feed, food and $\mathrm{CO}_{2}$ fixation demands. They should be more eco-efficient for using existing farmland or marginal (dry, waterlogged, saline) tracts. Although some advocate that bio-energy can play a role for mitigating climate change by reducing greenhouse emissions, appropriate life-cycle analysis will be needed on a case by case basis to determine the use of land resources and estimate net carbon emissions of each suggested renewable energy technology. The agenda for plant breeding may include increasing plant grain and biomass productivity, optimizing the chemical and physical attributes of biofuel sources, and improving specific traits in first- and second-generation biofuel crops, within a framework of sustainable agriculture.

A major goal of harmonizing agriculture with the environment is to "tailor" crops to individual landscapes. Plant breeding has always maximized production by selecting for adaptation in the target environments of interest, using local environmental forces for plant selection [75]. By selecting breeding germplasm growing under local environmental conditions, individual cultivars can be optimized for small regional areas of production that fit prevailing environmental and weather patterns. Likewise, plants could be tailored to provide specific ecosystem services to local environments, to address local needs. One cost-effective way to achieve this is through participatory plant breeding, which involves local farmers in the breeding process.

Alternative crop rotations, planting densities, and tillage systems may make production more environmentally benign but will require altering breeding targets and an understanding that systems biology is complex and rarely has simple solutions. For example, no-tillage systems used for soil conservation can lead to colder soils in spring and change the prevalence and onset of various soilborne diseases, thus requiring the addition of specific disease resistances in the breeding objectives [141]. Breeders must select from conditions prevailing under new management practices to ensure cultivars will be optimally productive.

\section{Impact of Transgenic Crops on Crop Biodiversity and Agro-Biodiversity}

The potential impact of transgenic crops on biodiversity has been a topic of interest both in general as well as specifically in the context of the Convention on Biological Diversity. In a recent review, Carpenter [142] took a biodiversity lens to the substantial body of literature existing on the potential impacts of genetically modified crops on the environment, considering the impacts at the crop, farm, and landscape scales. Overall, the review finds that currently commercialized transgenic crops have reduced the impacts of agriculture on biodiversity, through enhanced adoption of conservation tillage practices, reduction of insecticide use, and use of more environmentally benign herbicides. Increasing yields also alleviate pressure to convert additional land into agricultural use.

Respecting crop biodiversity is widely accepted, that greater varietal and species diversity would enable agricultural systems to maintain productivity over a wide range of conditions. With the introduction of transgenic crops, concern has been raised that crop genetic biodiversity will decrease since breeding programs will concentrate on a smaller number of high value cultivars. Three studies (two in the United States on cotton and soybean and one in India on cotton) have analyzed the impact on the introduction of transgenic crops within-crop genetic biodiversity [142]. Studies in the United States of genetic diversity on cotton and soybean both concluded that the introduction of transgenic cultivars was found to have little or no impact on biodiversity. In contrast, the introduction of Bt cotton in India initially resulted in a reduction of on-farm varietal biodiversity due to the introduction of technology in only a small number of cultivars, which has since been offset by more $B t$ cultivars becoming available over time [142]. Carpenter [142] concluded that from a broader perspective, transgenic crops may actually increase crop biodiversity by enhancing underutilized alternative crops, making them more suitable for widespread domestication.

Respecting agro-biodiversity plants have a major influence on soil communities of micro- and other organisms fundamental to many functions of soil systems, such as nitrogen cycling, decomposition of wastes, and 
mobilization of nutrients. The potential impact of Bt crops on soil organisms is well studied. A comprehensive review of the available literature, by Icoz and Stotzky [143], on the effects of Bt crops on soil ecosystems included the results of 70 scientific articles. The review found that, in general, few or no toxic effects of Cry proteins on woodlice, collembolans, mites, earthworms, nematodes, protozoa, and the activity of various enzymes in soil have been reported. Although some effects ranging from no effect to minor and significant effects, of $B t$ plants on microbial communities in soil have been reported, they were mostly the result of differences in geography, temperature, plant cultivar, and soil type and, in general, were transient and not related to the presence of the Cry proteins. Studies published since the Icoz and Stotzky review [143] have reached similar conclusions, including novel studies on snails.

In a study conducted in the northeastern part of the United States, Hoheisel and Fleischer [144] investigated the seasonal dynamics of coccinellids and their food (aphids and pollen) in a vegetable farm system containing plantings of Bt sweet corn, Bt potato, and transgenic insect-resistant squash [145]. The results indicated the transgenic vegetable crops provided conservation of coccinellids and resulted in a $25 \%$ reduction in insecticide use. In a similar study with these same crops, Leslie et al. [145] compared the soil surface-dwelling communities of Coleoptera and Formicidae in the transgenic crops and their isolines and found no differences in species richness and species composition but found that the transgenic vegetables required fewer insecticide applications. Such results are clear that genetically modified technology can be introduced within vegetable integrated pest management (IPM) systems and transgenic vegetables can offer novel and effective ways of controlling insects and the pathogens they transmit [54] [59].

Another main concern of transgenic crops is the unintentional spread of transgenic traits into weedy species [146]. There are examples of transgene escape and some evidence for selective advantage of herbicide resistance picked up by weeds [147] [148]. The risk of herbicide resistant genes from a transgenic crop cultivar being transferred to weed relatives has been demonstrated in field crops such as canola/oilseed rape [149] [150] and sugar beet [151]. Rose et al. [152] has demonstrated that a "transgenic mitigation strategy" may impart a negative genetic load to hybrids ensuing from crosses between the weed field mustard and oilseed rape crop. The transgenic mitigation measure was a fitness-mitigating dwarfing gene beneficial for crops but deleterious for weeds (i.e., the hybrid weed is dwarfed due to this mitigation gene and is therefore outgrown by its non-transgenic counterparts). This finding challenges the view that a transgenic plant might always endow a wild relative with a so-called fitness gene, making it harder and giving it the potential to become a "super-weed". Furthermore, Palaudelmàs et al. [153] found that transgenic maize volunteers had low plant vigor, rarely had cobs, and produced pollen which cross-fertilized neighbor plants only at low levels $(0.16 \%$ in the worst-case scenario and was below the Regulation EC 1830/2003 establishing the adventitious threshold of $0.9 \%$ for coexistence). Nonetheless, transgene flow raises a new set of ecological and economic issues for scientists and policy makers to consider for transgene containment.

Crop production practices also have significant effects on the composition of weed communities. Changes in the types of weeds that are important locally are termed weed shifts. Such shifts are particularly relevant for managing weeds in herbicide tolerant crop systems in which tillage practices and herbicide use both play major roles in shaping the weed community. There are reports in literature of fourteen weed species or groups of closely related species that have increased in abundance in glyphosate resistant crops [142]. At the same time in six states of the United States, in a survey of transgenic maize, soybean, and cotton growers, between $36 \%$ and $70 \%$ of growers indicated that weed pressure had declined after implementing rotations using glyphosate resistant crops. The use of herbicides can also result in changes to weed communities through the development of herbicide tolerant weed populations. Globally, glyphosate resistant weeds have been confirmed for 21 weeds in 15 countries [142]. Most of these cases have been reported where glyphosate resistant crops are commonly grown. The development of weeds resistant to glyphosate will most likely require modification to weed control programs where practices, in addition to applying glyphosate, are needed to control the resistant populations.

The introduction of herbicide tolerant transgenic crops has been associated with the increased adoption of conservation tillage practices, which decreases run-off, increases water infiltration and reduces erosion. Trends in the adoption of conservation tillage have been studied in the United States and Argentina, the largest growers of herbicide tolerant transgenic crops. While conservation tillage was already being adopted by some growers prior to the introduction of genetically modified herbicide tolerant crops in both countries, studies have shown a positive two-way causal relationship between the adoption of conservation tillage and the adoption of genetically modified herbicide tolerant crops. 
As stated, the most direct negative impact of agriculture on biodiversity is due to the considerable loss of natural habitats, which is caused by the conversion of natural ecosystems into agricultural land. Increases in crop yields allow less land to be dedicated to agriculture than it would otherwise be necessary. According to Carpenter [142] a large and growing body of literature has shown that the adoption of transgenic crops has increased yields, particularly in developing countries. A review of the results of global farmer surveys made by Carpenter [154], found the average yield increases for developing countries range from $16 \%$ for insect-resistant corn to $30 \%$ for insect-resistant cotton, with an 85\% yield increase observed in a single study on herbicide-tolerant corn. On average, developed-country farmers report yield increases ranging from no change for herbicide-tolerant cotton to a 7\% increase for herbicide-tolerant soybean and insect-resistant cotton. Brookes et al. [155] have estimated the benefit of these yield improvements by reducing conversion of land into agricultural use. They estimate that 2.64 million hectares of land would probably be brought into grain and oilseed production if biotechnology traits were no longer used.

Storer et al. [156] stated that the most direct landscape level effects of growing Bt crops would be expected for target pest species for which the crop is a primary food source and is mobile across the landscape. Area-wide pest suppression not only reduces losses to adopters of technology, but may also benefit non-adopters and growers of other crops by reducing crop losses and/or the need to use pest control measures such as insecticides [142].

Several studies have investigated the impact on the introduction of $B t$ corn and cotton on regional outbreaks of pest populations, reporting evidence of regional pest suppression in $B t$ corn and cotton in various areas of the United States and in Bt cotton growing regions of China [142] [157]-[161]. The effects of transgenic crops on above-ground non-target invertebrates have been the subject of a large number of laboratory and field studies. By the end of 2008, over 360 original research papers had been published on non-target effects of $B t$ crops [161]. A comprehensive review of the literature by Naranjo [161] included 135 laboratory-based studies on nine Bt crops from 17 countries and 63 field-based studies on five $B t$ crops from 13 countries, which were analyzed using meta-analysis techniques. In general, laboratory studies identified greater levels of hazard than field studies, at least partially explained by differences in organisms studied, and frequently higher protein exposure in lab studies compared to exposure levels in the field [161] [162]. Field studies demonstrated few harmful non-target effects, with non-target effects of insecticides being much greater than Bt crops[161] [162]. More recent literature on non-target impacts of Bt crops are largely consistent with Naranjo's conclusions [142]. Studies on nontarget impacts of herbicide tolerant crops, such as the United Kingdom Farm Scale Evaluations (FSE), have found that the effects on various groups of arthropods followed the effects on the abundance of their resources. Where weed control was more effective, the reduction in weeds and weed seeds led to decreases in insects which live in or on weeds, and vice versa. Other studies on non-target impacts of herbicide tolerant crops, conducted for herbicide tolerant soybean and maize in the United States and herbicide tolerant canola in Canada, have reached similar conclusions. FSE results on the bird survey were in accord with differences in food availability found in the studies. Specifically, a greater abundance of granivores was found on conventional than on genetically engineered herbicide tolerant sugar beet, as well as on genetically engineered herbicide tolerant maize after application of herbicides to the genetically modified herbicide tolerant field. No differences were detected in spring oilseed rape. In the subsequent winter season, granivores were more abundant in fields where conventional sugar beet had been grown than on genetically engineered herbicide tolerant fields. Several bird species were more abundant on maize stubbles following genetically engineered herbicide tolerant treatment [142].

The pest management traits embodied in currently commercialized transgenic crops have led to changes in the use of pesticides which may have impacts on biodiversity. If the planting of genetically modified pest-resistant crop cultivars eliminates the need for broad-spectrum insecticidal control of primary pests, naturally occurring control agents are more likely to suppress secondary pest populations, maintaining a diversity and abundance of prey for birds, rodents, and amphibians. In addition to the studies on the non-target impacts of transgenic crops compared to conventional practices, many studies have quantified changes in pesticide use since the introduction of genetically modified crops. Reductions ranging from $14 \%$ to $75 \%$ of total active ingredients have been reported for Bt crops compared to conventional crops in Argentina, Australia, China, India, and the United States [142]. Brookes and Barfoot [163] indicated that transgenic crops grown by farmers were able to lower pesticide spraying by $443 \mathrm{~kg}(9.1 \%)$ of active ingredients, thereby decreasing the environmental impact associated with herbicide and insecticide use by $17.9 \%$. These authors also emphasize that transgenic crops significantly re- 
duced the release of greenhouse gas emissions from their cropping area, which was equivalent, in 2010, to removing 8.6 million cars from the roads. Fewer surveys have captured changes in herbicide use in genetically modified herbicide tolerant crops, perhaps because the impact of genetically modified herbicide tolerant crops has largely been a substitution between herbicides applied at different rates, and therefore, changes in the amount of herbicide used is a poor indicator of environmental impact. Several studies have been done to apply environmental indicators to observed changes in pesticide use related to the adoption of both insect resistant and herbicide tolerant crops, which all show a reduction in the environmental impact of pesticides used on transgenic crops [142]. A life cycle assessment made by Bennet et al. [164] showing that transgenic sugar beet tolerating herbicide would be less harmful to the environment than the conventional sugar beet crop because of the lower emissions from herbicide manufacture, transport, and field operations.

Some benefits of genetically modified crops are expected to decline over time, and potential benefits and risks may become more numerous as technology is applied to more crops [165]. For example the plants from $B t$ cotton seed have been effective in controlling damage from bollworm (Helicoverpa armigera) in Chinese cotton production since 1999, reducing the need for pesticides and increasing incomes of Chinese farmers. However, field data collected in 2004 indicates that these benefits are being eroded by an increasing use of pesticides aimed at the control of secondary pests [166]. This was confirmed in 2009 by Wang et al. [167], who claimed that the increased problems with secondary pests were of less importance than the decreased use of insecticides due to growing $B t$ cotton. In United States maize fields another pest, the rootworm has developed resistance to the toxin from Bt, as reported by the Environmental Protection Agency [168].

Knowledge gained over the past 15 years that genetically modified crops have been grown commercially indicates the impacts on biodiversity are positive on balance. By increasing yields, decreasing insecticide use, increasing use of more environmentally friendly herbicides, and facilitating adoption of conservation tillage, transgenic crops have contributed to increasing agricultural sustainability. Previous reviews have also reached the general conclusion that genetically modified crops have had little to no negative impact on the environment [142] [161]. Most recently, the United States National Research Council released a comprehensive assessment of the effect of genetically modified crop adoption on farm sustainability in the United States which concluded: "generally, genetically modified crops have had fewer adverse effects on the environment than non-genetically modified crops produced conventionally" [165]. Thus, transgenic crops can continue to decrease pressure on biodiversity as global agricultural systems expand to feed a world population expected to continue to increase for the next 30 to 40 years.

\section{Conservation and Use of Biodiversity: Opportunities for Cooperation and New Partnerships}

Plant genetic resources for food and agriculture are the quintessential global public good. No nation is self-reliant. A viable market for their conservation and trade does not exist. The conservation of plant genetic resources is a prerequisite for addressing climate change, as well as water and energy constraints, which will grow in importance in the next decades. The Svalbard Global Seed Vault is an International Treaty which establishes a multilateral System to facilitate access and benefit sharing of plant genetic resources. The Treaty has an insurance policy and provides legal framework for a cooperative and global approach to manage this essential resource. The Svalbard Global Seed Vault has a mechanism for ensuring the permanent conservation of unique crop biodiversity, the Global Crop Diversity Trust, which is structured as an endowment fund [169].

Plant breeding is vital to protect the yield gains made to date, and to further increase the genetic yield potential of all crops. As a result of the Green Revolution, global productivity of the main food staples steadily rose since the 1960s. Such achievements ensued from crop genetic enhancement partnerships. They are models illustrating partnering for exchange, evaluation, release and use of plant genetic resources worldwide. These partnerships include national agricultural research institutes and international agricultural research centers. For many decades the global wheat yield increased due to an effective International Wheat Improvement Network (IWIN) officially founded as an international organization in 1966 [170]. This wheat network deployed cutting-edge science alongside practical multi-disciplinary applications, resulting in the development of genetically enhanced wheat germplasm, which has improved food security and the livelihoods of farmers in the developing world [171]. The spring wheat germplasm bred in Mexico under the leadership of Nobel Peace Laureate Norman Borlaug was further used for launching the Green Revolution in India, Pakistan and Turkey [172]. The network was 
broadened during the 1970s to include Brazil, China and other major developing country wheat producers. It resulted in wheat cultivars with broader host plant resistance (especially to rusts), better adaptation to marginal environments, and tolerance to acid soils. Nowadays IWIN, an international "alliance", operates field evaluation trials in more than 250 locations, in roughly 100 countries it tests improved breeding lines of wheat in different environments. The number of wheat cultivars released annually in the developing world doubled to more than 100 cultivars by early 1990s due to this networking and the strengthening of national capacity [173]. The widespread adoption of newly bred wheat cultivars, especially in South Asia and Latin America, due to yield increases, led to 50\% average annual rates of investment returns [174]. The urban poor also benefited significantly because grain harvest increases drove wheat prices down. Every year, nursery sets and trials are sent to various researchers worldwide, who share their data from these trials to catalogue and analyze. The returned data are used to identify parents for subsequent crosses and to incorporate new genetic variability into advanced wheat lines that are consequently able to cope with the dynamics of abiotic and biotic stresses affecting wheat farming systems. The full pedigree and selection histories are known and phenotypic data cover yield, agronomic, pathological and quality data [171].

The International Network for Genetic Evaluation of Rice (INGER) is one more example of world cooperation. It was established in 1975 as a consortium of national agricultural research systems of rice-growing countries and Centers of today's CGIAR Consortium. INGER was initially founded as an International Rice Testing Program, but soon became an integral component of world national rice breeding program. INGER partners can share rice breeding lines. Every year partners provide about 1000 genetically diverse breeding lines, which have been grown in about 600 experiment stations from 80 countries. This network facilitated the release of 667 cultivars worldwide, which translated into 1.5 billion US dollars of economic benefits. It was estimated that ending INGER could lead to a reduction of 20 rice cultivars per year and to an economic loss of 1.9 billion US dollars [175]. Further analysis by Jackson and Huggan [176] has shown how genetic conservation of landraces can lead to significant gains in rice breeding.

Two other examples of cooperation and partnership are the Latin American Maize Project (LAMP) and the Germplasm Enhancement of Maize (GEM). The LAMP was established as a partnership between Latin America and the United States to assess national germplasm and facilitate the exchange of maize genetic resources across the American continent [177]. The United States Department of Agriculture, the participating national agricultural research systems and a multinational seed corporation provided the funding. The aim of LAMP was to obtain information about the performance of maize germplasm and to share it with plant breeders for developing genetically enhanced open pollinated and hybrid cultivars. The maize germplasm was tested for agronomic characteristics from sea level to $3300 \mathrm{~m}$, and from $41^{\circ} \mathrm{N}$ to $34^{\circ} \mathrm{S}$ across 32 locations in the first stage and in 64 locations (two per region) in the second stage. These locations were clustered according to five homologous areas: lowland tropics, temperate and three altitudes.

There were a total five LAMP breeding stages [177]. In the first stage, 14,847 maize accessions belonging to a region were planted for evaluation in trials using a randomized complete block design with two replications of $10 \mathrm{~m}^{2}$ plots at a single location, which was environmentally similar to that from where these landraces were originally collected. The next step included the assessment of the upper quintile (20\%) of those accessions evaluated for agronomic performance in the previous stage. These accessions were planted in two locations with two replications, and the upper $5 \%$ were further selected according to their performance. These best selected accessions of each country were interchanged among regions belonging to the same homologous area in the third stage. They were tested in two locations with two replications in each region. The selected maize accessions from the same homologous area were mated with the best tested accession of the region in an isolated field within each region. In the fourth stage, combining ability tests of 268 selected maize accessions were carried out with a local tester using two replications at two locations within each region. The elite maize germplasm was integrated into breeding programs in the fifth stage, which was the last. The best cross combinations and heterotic pools were also determined by LAMP. Maize breeders obtained access to the most promising accessions identified by LAMP to widen the crop genetic base. A LAMP core subset has been made available for encouraging further use in broadening of maize genetic diversity [178].

The GEM was set up to introgress useful genetic diversity from Latin American maize landraces and other tropical maize donor sources (lines and hybrids) into United States' maize germplasm, to broaden the genetic base of the "corn-belt" hybrids [179] [180]. GEM owes its existence to LAMP because it has used the Latin American landrace maize accessions selected by LAMP in crosses with elite temperate maize lines from the 
private seed companies in North America [177]. GEM used a pedigree breeding system to develop $\mathrm{S}_{3}$ lines. The GEM breeders arranged their crosses into non-Stiff Stalk and Stiff Stalk heterotic groups [181].

LAMP provided the first step through the sharing of information needed to select gene bank maize accessions for further germplasm enhancement. GEM completed the process by returning to genetically enhanced breeding materials derived from gene bank accessions. This improved germplasm can be further used in maize breeding in the United States and elsewhere. LAMP and GEM are very nice examples of international and national public-private partnerships in crop germplasm enhancement.

Agricultural plant breeding is a typical commodity- or species-oriented and solves problems within a species, rather than making breeding choices based on system wide needs. For example, maize breeders currently maximize the area in which maize can be grown, and maximize the amount of maize produced throughout that area. If environmental harmony is to be a key breeding objective, then a change in agricultural thinking to appropriately value whole cropping systems will be required. Achieving these goals will require collaboration among the private, public, and non-profit sectors, and with society as a whole. Programs within the private sector excel at breeding major, profitable crops, and have economies of scale to increase the efficiency of production and ultimately provide farmers with seed. As a valuable complement to commercial breeding programs, public and non-profit breeding programs may focus on developing alternative crops, breeding for small target regions, tackling long-term and high-risk problems, evaluating diverse genetic resources, and, importantly, conducting basic research on breeding methodology to enhance efficiency. Only publicly funded breeding programs, and in particular those based at universities, can provide the necessary education and training in plant breeding and in specialized fields such as ecology. Without trained students from public programs, private commercial breeding programs suffer from an erosion of intellectual capital. Conversely, without the private sector to commercialize public-sector-derived products, beneficial traits and new cultivars cannot easily and quickly be put in the hands of farmers, as has been seen in developing countries without a developed seed industry [182]. As stated, seed production is high technology and a cost intensive venture and only well organized seed companies with good scientific manpower and well equipped research facilities can afford seed production.

Although due to globalization, most breeding research and cultivar development in the world is presently conducted and funded in the private sector, mainly by huge multinational seed companies. Public breeders, cultivar development activities and research are disappearing worldwide. In general, this means there are fewer decision-making centers for breeding and cultivar development. This has also resulted in the focus on relatively few major crops produced worldwide, to the detriment of all the other cultivated crops. It is imperative that national governments and policymakers, as part of a social duty, invest in breeding research and cultivar development of traditional open-pollinated cultivars and in the minor crops. More investments in this area will mean less expensive seed for growers to choose from, and an increased preservation of crop biodiversity. To accomplish these goals new approaches may be required to crop breeding research and development by both the public and private sector. Until recently, breeding research and development which targets small-scale and poor farmers has largely been undertaken by public sector institutions and national agricultural research institutes. However, the capacity to undertake the work was mainly dependent on national or international funding and expertise. The work has been limited by the capacity of these institutions to pay for it. As a result, crop breeding advancement has varied enormously among countries and even within regions in developed and still developing countries. In the area of plant breeding, the process to produce improved cultivars is slow, and it requires long-term sustained commitment that may not fit the continuing changes in the national and international politics to fund research. The application of biotechnology promises acceleration in some aspects of plant breeding, but the adoption of more advanced technology raises the cost of research significantly at a time when investment funding has diminished. Public plant breeding remains a key component of crop breeding research systems worldwide, especially in developing countries. However, the increasing presence of private sector breeding and a decrease in national and international support makes it difficult for the public sector to continue operating in the traditional manner. Declining funding for public crop breeding coupled with the rapid increase of crop production and an urbanizing population has created a difficult situation. Public sector breeding must be strengthened. More public sector crop breeders are needed worldwide to select and to produce non-hybrid cultivars of the minor crops. Breeding of major crops and other minor crops must continue as a viable endeavor. This will benefit small farmers, and will safeguard biodiversity and food security in developing countries.

While the maintenance of vigorous public sector breeding programs in areas where private companies are not interested in providing low cost cultivars is highly desirable, an additional approach to maximize crop and agri- 
cultural research input would be the development of global programs with public-private partnerships. The public sector may support portions of crop and agricultural R \& D, unattractive to the private sector, and feed improved breeding lines and systems to the private sector for exploitation in regions where the private sector is active, and nurture private sector development in regions where it is lacking. In recent years, private plant breeding programs have increased in number and size. Financial investment also increased, as well as interest in intellectual property protection. The spirit of original attempts to protect plant breeders' rights was that granting a certificate of protection should not inhibit the flow of information and products through continued research by the entire plant breeding community [49] [50]. In a classic sense, the patent is a defensive tool to prevent competitors from reaping benefits which rightfully belong to the inventor. In the modern context, it is an offensive weapon, to stifle competition, prevent further innovation by others and maximize income [49] [51]. The United States utility patent, it is a way to slow down the flow of progress in plant breeding research, unless the research is within the company holding the patent. While obviously benefiting that company, it is a big step backwards for the plant breeding community and by far, for agriculture itself. The intellectual property protection must encourage research and free flow of materials and information [49] [51]. Protection should be for the cultivar only. There should be no constraint against other breeders using that cultivar in further research, including further breeding. Another breeder should be free to use the protected cultivar in a cross, followed by further development through pedigree breeding. Another breeder should also be free to transfer genes controlling economic traits into the protected cultivar by the backcross method or by genetic transformation procedures [49] [50].

\section{Conclusions}

The growing demand for food in the next decades poses major challenges to humanity. We have to safeguard both biodiversity and arable land for future agricultural food production, and we need to protect genetic biodiversity to safeguard ecosystem resilience. We must produce more food with less input, while deploying every effort to minimize risk. Agricultural sustainability is no longer an option, it is mandatory!

Plant breeding is the science of improving plants to further improve the human condition. Plant breeding has played a vital role in the successful development of modern agriculture via "new" cultivars. Plant breeders are continually improving the ability of cultivars to withstand various environmental conditions. By reducing the impact of agriculture on the environment while maintaining sufficient production will require the development of new cultivars.

Climate change is altering the availability of resources and the conditions crucial to plant performance. Plants respond to these changes through environmentally induced shift in phenotype. Understanding these responses is essential to predict and manage the effects of climate change on crop plants.

In the foreseeable future and an increase in population will need significant production. Breeding and modern agricultural technologies can increase yield on existing agricultural land. As a result, they can make a significant contribution to biodiversity conservation by limiting the need to expand agricultural land and by allowing nature to be maintained for conservation purposes and harmony between agriculture and the environment.

There is still an on-going debate among researchers and in the media on the best strategy to keep pace with global population growth and increasing food demand. One strategy favors the use of transgenic crops, while another strategy focuses on agricultural biodiversity. There are short research funds for agro-biodiversity solutions in comparison with funding for research in genetic modification of crops. Favoring biodiversity does not exclude any future biotechnological contributions, but favoring biotechnology threatens future biodiversity resources. The future breeding programs should encompass not only knowledge of existing practices but also conservation of a wide pool of genetic resources of existing crops and breeds, including their wild relatives, to provide the genes necessary to cope with changes in agricultural production. Therefore, agro-biodiversity should be a central element of future sustainable agricultural development, instead of just a source of traits which can be used in current breeding programs. The concept of sustainability rests on the principle that the present needs must be addressed without compromising the ability of future generations to meet their own needs. Sustainable agriculture is an alternative to solve future fundamental and applied issues related to food production in an ecological way.

Farmers in developing countries, especially small farmers, have problems specific to their cultural, economic and environmental conditions, such as limited purchasing power to access improved cultivars and proprietary technologies. These farmers have an important role in conserving and using crop biodiversity. The future of the 
world food security depends on stored crop genes as well as on farmers who use and maintain crop genetic diversity on a daily basis. In the long run, the conservation of plant genetic diversity depends not only on a small number of institutional plant breeders and seed banks, but also on the vast number of farmers who select, improve, and use crop diversity, especially in marginal farming environments. Their extensive farming systems using landraces or open-pollinated cultivars increase sustainability and less impact from stresses caused by drought, insect and diseases, due to long-term in situ selection of these crops cultivated as opposed to the fertilizer, herbicide, and pesticide demands in an intensive crop based system with improved, hybrid, or transgenic cultivars. That is why we should also be alerted and particularly alarmed by the current trend to exclusively use improved, hybrid, and transgenic crop cultivars. Farmers do not just save seeds; they are plant breeders who constantly adapt their crops to specific farming conditions and needs. This genetic biodiversity is the key to maintain and improve the world's food security, and agriculture sustainability.

The introduction of genetically modified technology has been hailed as a gene revolution similar to the "Green Revolution" of the 1960s. The "Green Revolution" had an explicit strategy for technology development and diffusion, targeting farmers in developing countries, in which improved germplasm was made freely available as a public good, a particular success in Asia. In contrast to the "Green Revolution", the push for genetically modified crops is based largely on private agricultural research, with cultivars provided to farmers on market terms. To date efforts on genetically modified crops have been focused on crops considered to be profitable enough by large plant breeding companies, not on solutions to problems confronted by the world's small farmers. Existing biodiversity in combination with plant breeding has much more to offer the many world's farmers and consumers, while genetically modified crops have more to offer the agro-industry and some largescale farms, and this explains why they have received so much attention and research funding. Genetically modified crops and their creation may attract investment in agriculture, but it can also concentrate ownership of agricultural resources. In developing countries, patents may drive up costs; restrict experimentation by the public researcher or individual farmer, while undermining local practices that enhance food security and economic sustainability. There is particular concern that present intellectual property rights instruments, including genetically modified organisms, will inhibit sowing of own seeds, seed exchange, and sale.

Transgenic crops can continue to decrease pressure on biodiversity as global agricultural systems expand to feed a world population expected to continue to increase for the next 30 to 40 years. Due to higher income elasticity of demand and population growth, these pressures will be greater in developing countries. Both current and pipeline technology hold great potential in this regard. The potential of currently commercialized genetically modified crops to increase yields, decrease pesticide use, and facilitate the adoption of conservation tillage has yet to be realized, as there continue to be countries where there is a good technological fit, but they have not yet approved these technologies for commercialization. In addition to the potential benefits on expanded adoption of current technology, several pipeline technologies offer additional promises of alleviating the impacts of agriculture on biodiversity. Continued yield improvements in crops such as rice and wheat are expected with insect resistant and herbicide tolerant traits that are already commercialized in other crops. Technologies such as drought tolerance and salinity tolerance would alleviate the pressure to convert high biodiversity areas into agricultural use by enabling crop production on sub-optimal soils. Drought tolerance technology, which allows crops to withstand prolonged periods of low soil moisture, is anticipated to be commercialized within less than five years. This technology has particular relevance for areas like sub-Saharan Africa, where drought is a common occurrence and access to irrigation is limited. Salt tolerance addresses the increasing problem of saltwater encroachment on freshwater resources. Nitrogen use efficient technology is also under development, which can reduce run-off of nitrogen fertilizer into surface waters. Technology promises to decrease the use of fertilizers while maintaining yields, or increase yields achievable with reduced fertilizer rates where access to fertilizer input is limited. This technology is slated to be commercialized within the next 10 years.

One of the major arguments for genetic modified technology is that new cultivars can be developed more quickly than in traditional plant breeding, but like new cultivars derived from conventional breeding methods, transgenic cultivars require several years of field trials to ensure that the inserted traits will actually become expressed and have the desired effects in local environments. When genes coding for certain traits are transferred, typically from one plant species to another, the desired traits are not always expressed unless the environment interacts with the genes in the anticipated way triggering the desired response, which depends on the regulating sequences inserted with the gene. This means that new transgenic cultivars, developed under laboratory conditions in a controlled climate, have to be tested under field conditions, as in more traditional breeding methods, so 
currently there is little difference in the speed with which either method will result in the release of new cultivars.

The knowledge gained from basic plant research will underpin future crop improvements, but effective mechanisms for the rapid and effective translation of research discoveries into public good agriculture remain to be developed. Maximum benefit will be derived if robust plant breeding and crop management programs have ready access to all the modern crop biotechnological techniques, both transgenic and non-transgenic, to address food security issues. This will require additional investments in capacity building for research and development, in developing countries. Technology implementation alone is not sufficient to address such complex questions as food security. Biotechnologies will make new options available but are not a global solution. We must ensure that society will continue to benefit from the vital contribution that plant breeding offers, using both conventional and biotechnological tools. Genetic engineering has the potential to address some of the most challenging biotic constraints faced by farmers, which are not easily addressed through conventional plant breeding alone. Besides other promising traits seems to be host plant resistance to insects and pathogens. However, transgenic cultivars will have one or a few exogenous genes whereas the background genotype will still be the product of non-transgenic (or conventional) crop breeding. One should follow a pragmatic approach when deciding whether to engage in transgenic plant breeding. Biotechnology products will be successful if clear advantages and safety are demonstrated to both farmers and consumers.

There is a need of investment in research breeding and cultivar development in traditionally open-pollinated cultivars and in the minor crops. More investments in this area will mean cheaper cultivars for growers to choose from and more preservation of crop biodiversity. In recent years, private plant breeding programs have increased in number and size. Financial investment also increased, as well as interest in intellectual property protection. Protective measures, especially patenting, must be moderated to eliminate coverage so broad that it stifles innovation. The intellectual property protection laws for plants must be made less restrictive to encourage research and free flow of materials and information. Public sector breeding must remain vigorous, especially in areas where the private sector does not function. This will often require benevolent public/private partnerships as well as government support. Intellectual property rights laws for plants must be made less restrictive to encourage freer flow of materials. Active and positive connections between the private and public breeding sectors and large-scale gene banks are required to avoid a possible conflict involving breeders' rights, gene preservation and erosion. Partnerships between policy makers with public and private plant breeders will be essential to address future challenges. Many current breeding efforts remain under-funded and disorganized. There is a great need for a more focused, coordinated approach to efficiently utilize funding, share expertise, and continue progress in technologies and programs.

\section{References}

[1] Jaggard, K.W., Qi, A.M. and Ober, E.S. (2010) Possible Changes to Arable Crop Yields by 2050. Philosophical Transactions of the Royal Society B: Biological Sciences, 365, 2835-2851. http://dx.doi.org/10.1098/rstb.2010.0153

[2] FAO (2012) The State of the World Population Report. By Choice, Not by Chance: Family Planning, Human Rights and Development. United Nations Population Fund, New York.

[3] da Silva Dias, J.C. (2014) Guiding Strategies for Breeding Vegetable Cultivars. Agricultural Sciences, 5, 9-32. http://dx.doi.org/10.4236/as.2014.51002

[4] Dias, J.S. and Ryder, E.J. (2011) World Vegetable Industry: Production, Breeding, Trends. Horticultural Reviews, 38, 299-356.

[5] Dias, J.S. (2012) Chapter 1. Vegetable Breeding for Nutritional Quality and Health Benefits. In: Carbone, K., Ed., Cultivars: Chemical Properties, Antioxidant Activities and Health Benefits, Nova Science Publishers, Inc., Hauppauge, $1-81$.

[6] Tilman, D., Balzer, C., Hill, J. and Befort, B.L. (2011) Global Food Demand and the Sustainable Intensification of Agriculture. Proceedings of the National Academy of Sciences of the United States of America, 108, 20260-20264. http://dx.doi.org/10.1073/pnas.1116437108

[7] Alexandratos, N. and Bruinsma, J. (2012) World Agriculture towards 2030/2050: The 2012 Revision. Paper No. 12-03, Food and Agriculture Organization (FAO), Rome.

[8] FAO (2012) How to Feed the World in 2050. FAO, Rome.

[9] Delgado, C.L. (2003) Rising Consumption of Meat and Milk in Developing Countries Has Created a New Food Revo- 
lution. Journal of Nutrition, 133, 3907S-3910S.

[10] Kastner, T., Rivas, M.J.I., Koch, W. and Nonhebel, S. (2012) Global Changes in Diets and the Consequences for Land Requirements for Food. Proceedings of the National Academy of Sciences of the United States of America, 109, 68686872. http://dx.doi.org/10.1073/pnas.1117054109

[11] Delgado, C.L. (1999) Livestock to 2020: The Next Food Revolution. Food, Agriculture, and the Environment Discussion Paper No. 28, International Food Policy Research Institute, Washington DC.

[12] The Royal Society (2009) Reaping the Benefits: Science and the Sustainable Intensification of Global Agriculture. The Royal Society Policy Document 11/09, The Royal Society, London.

[13] Naylor, R., Steinfeld, H., Falcon, W., Galloway, J., Smil, V., Bradford, E., Alder, J. and Mooney, H. (2005) Losing the Links between Livestock and Land. Science, 310, 1621-1622.

[14] Gerbens-Leenes, P. and Nonhebel, S. (2002) Consumption Patterns and Their Effects on Land Required for Food. Ecological Economics, 42, 185-199. http://dx.doi.org/10.1016/S0921-8009(02)00049-6

[15] Wirsenius, S., Azar, C. and Berndes, G. (2010) How Much Land Is Needed for Global Food Production under Scenarios of Dietary Changes and Livestock Productivity Increases in 2030? Agricultural Systems, 103, 621-638. http://dx.doi.org/10.1016/j.agsy.2010.07.005

[16] Pimentel, D. and Pimentel, M. (2003) Sustainability of Meat-Based and Plant-Based Diets and the Environment. American Journal of Clinical Nutrition, 78, 660S-663S.

[17] Foley, J.A., Ramankutty, N., Brauman, K.A., Cassidy, E.S., Gerber, J.S., Johnston, M., Mueller, N.D., O’Connell, C., Ray, D.K., West, P.C., Balzer, C., Bennett, E.M., Carpenter, S.R., Hill, J., Monfreda, C., Polasky, S., Rockström, J., Sheehan, J., Siebert, S., Tilman, D. and Zaks, D.P. (2011) Solutions for a Cultivated Planet. Nature, 478, 337-342. http://dx.doi.org/10.1038/nature10452

[18] Steinfeld, H., Gerber, P., Wassenaar, T., Castel, V., Rosales, M. and De Haan, C. (2006) Livestock’s Long Shadow: Environmental Issues and Options. FAO, Rome.

[19] Mekonnen, M.M. and Hoekstra, A.Y. (2012) A Global Assessment of the Water Footprint of Farm Animal Products. Ecosystems, 15, 401-415. http://dx.doi.org/10.1007/s10021-011-9517-8

[20] World Watch Institute (2010) Biofuel Production Up Despite Economic Downturn Vital Signs. World Watch Institute, New York.

[21] Food and Agricultural Policy Research Institute (FAPRI) (2011) World Biofuels: FAPRI-ISU 2011 Agricultural Outlook. FAPRI, Ames.

[22] FAO (2013) FAO Statistical Yearbook—Land Use. FAOSTAT, FAO, Rome, PA4.

[23] Kucharik, C.J. and Serbin, S.P. (2008) Impact of Recent Climate Change on Wisconsin Corn and Soybean Yield Trends. Environmental Research Letters, 3, Article ID: 034003, 10 p.

[24] Battisti, D.S. and Naylor, R.L. (2009) Historical Warnings of Future Food Insecurity with Unprecedented Seasonal Heat. Science, 323, 240-244. http://dx.doi.org/10.1126/science.1164363

[25] Schlenker, W. and Lobell, D.B. (2010) Robust Negative Impacts of Climate Change on African Agriculture. Environmental Research Letters, 5, Article ID: 014010, 8 p.

[26] Roudier, P., Sultan, B., Quirion, P. and Berg, A. (2011) The Impact of Future Climate Change on West African Crop Yields: What Does the Recent Literature Say? Global Environmental Change, 21, 1073-1083. http://dx.doi.org/10.1016/j.gloenvcha.2011.04.007

[27] Lobell, D.B., Schlenker, W. and Costa-Roberts, J. (2011) Climate Trends and Global Crop Production since 1980. Science, 333, 616-620. http://dx.doi.org/10.1126/science.1204531

[28] Lobell, D.B., Bänziger, M., Magorokosho, C. and Vivek, B. (2011) Nonlinear Heat Effects on African Maize as Evidenced by Historical Yield Trials. Nature Climate Change, 1, 42-45. http://dx.doi.org/10.1038/nclimate1043

[29] Schlenker, W. and Roberts, M.J. (2009) Nonlinear Temperature Effects Indicate Severe Damages to US Crop Yields under Climate Change. Proceedings of the National Academy of Sciences of the United States of America, 106, 1559415598. http://dx.doi.org/10.1073/pnas.0906865106

[30] Gupta, R., Gopal, R., Jat, M.L., Jat, R.K., Sidhu, H.S., Minhas, P.S. and Malik, R.K. (2010) Wheat Productivity in Indo-Gangetic Plains of India during 2010: Terminal Heat Effects and Mitigation Strategies. PACA Newsletter, 14, $1-11$.

[31] Asseng, S., Foster, I. and Turner, N.C. (2011) The Impact of Temperature Variability on Wheat Yields. Global Change Biology, 17, 997-1012. http://dx.doi.org/10.1111/j.1365-2486.2010.02262.x

[32] Lobell, D.B., Sibley, A. and Ortiz-Monasterio, J.I. (2012) Extreme Heat Effects on Wheat Senescence in India. Nature Climate Change, 2, 186-189. http://dx.doi.org/10.1038/nclimate1356 
[33] Bell, G. and Collins, S. (2008) Adaptation, Extinction and Global Change. Evolutionary Applications, 1, 3-16.

[34] Kelly, A.E. and Goulden, M.L. (2008) Rapid Shifts in Plant Distribution with Recent Climate Change. Proceedings of the National Academy of Sciences of the United States of America, 105, 11823-11826. http://dx.doi.org/10.1073/pnas.0802891105

[35] Shanthi-Prabha, V., Sreekanth, N.P., Babu, P.K. and Thomas, A.P. (2011) The Trilemma of Soil Carbon Degradation, Climate Change and Food Insecurity. Disaster Risk and Vulnerability Conference 2011, The Applied Geoinformatics for Society and Environment, Germany, 107-112.

[36] Gregory, P.J., Johnson, S.N., Newton, A.C. and Ingram, J.S.I. (2009) Integrating Pests and Pathogens into the Climate Change/Food Security Debate. Journal of Experimental Botany, 60, 2827-2838. http://dx.doi.org/10.1093/jxb/erp080

[37] Patz, J.A. and Kovats, R.S. (2002) Hot Spots in Climate Change and Human Health: Present and Future Risks. Lancet, 368, 859-869.

[38] Mcmichael, A., Woodruff, R.E. and Hales, S. (2006) Climate Change and Human Health: Present and Future Risks. Lancet, 367, 859-869. http://dx.doi.org/10.1016/S0140-6736(06)68079-3

[39] Ziska, L.H., Epstein, P.R. and Schlesinger, W.H. (2009) Rising $\mathrm{CO}_{2}$, Climate Change, and Public Health: Exploring the Links to Plant Biology. Environmental Health Perspectives, 117, 155-158. http://dx.doi.org/10.1289/ehp.11501

[40] Borlaug, N. (1983) Contributions of Conventional Plant Breeding to Food Production. Science, 219, 689-693. http://dx.doi.org/10.1126/science.219.4585.689

[41] Trethowan, R.M., Reynolds, M.P., Ortiz-Monasterio, I. and Ortiz, R. (2007) The Genetic Basis of the Green Revolution in Wheat Production. Plant Breeding Reviews, 28, 39-58. http://dx.doi.org/10.1002/9780470168028.ch2

[42] Evenson, R.E. and Gollin, D. (2003) Assessing the Impact of the Green Revolution, 1960 to 2000. Science, 300, 758762. http://dx.doi.org/10.1126/science.1078710

[43] Tilman, D., Cassman, K.G., Matson, P.A., Naylor, R. and Polasky, S. (2002) Agricultural Sustainability and Intensive Production Practices. Nature, 418, 671-677. http://dx.doi.org/10.1038/nature01014

[44] Burney, J.A., Davis, S.J. and Lobell, D.B. (2010) Greenhouse Gas Mitigation by Agricultural Intensification. Proceedings of the National Academy of Sciences of the United States of America, 107, 12052-12057. http://dx.doi.org/10.1073/pnas.0914216107

[45] Edgerton, M.D. (2009) Increasing Crop Productivity to Meet Global Needs for Feed, Food, and Fuel. Plant Physiology, 149, 7-13. http://dx.doi.org/10.1104/pp.108.130195

[46] IAASTD (2009) Agriculture at the Crossroads. International Assessment of Agricultural Knowledge, Science and Technology for Development (IAASTD). Island Press, Washington DC.

[47] Harlan, J.R. (1992) Crops and Man. American Society of Agronomy and Crop Science Society of America, Madison.

[48] Pratt, R.C. (2004) An Historical Examination of the Development and Adoption of Hybrid Corn: A Case Study in Ohio. Maydica, 49, 155-172.

[49] Dias, J.S. (2011) Biodiversity and Vegetable Breeding in the Light of Developments in Intellectual Property Rights. In: Grillo, O. and Verona, G., Eds., Ecosystems Biodiversity, Chapter 17, INTECH publisher, Rijeka, 389-428.

[50] Dias, J.S. (2012) Impact of the Vegetable Breeding Industry and Intellectual Property Rights in Biodiversity and Food Security. In: Jones, A.M. and Hernandez, F.E., Eds., Food Security: Quality, Management, Issues and Economic Implications, Nova Science Publishers Inc., Hauppauge, 57-86.

[51] Dias, J.S. (2013) Impact of Vegetable Breeding Industry and Intellectual Property Rights in Food Security. In: Nath, P., Ed., The Basics of Human Civilization-Food, Agriculture and Humanity, Vol. I. Present Scenario, Prem Nath Agricultural Science Foundation (PNASF), Bangalore \& New India Publishing Agency (NIPA), New Delhi, 173-198.

[52] Dias, J.S. and Ryder, E. (2012) Impact of Plant Breeding on the World Vegetable Industry. Acta Horticulturae, 935, 13-22.

[53] Dias, J.S. (2010) Impact of Improved Vegetable Cultivars in Overcoming Food Insecurity. In: Nath, P. and Gaddagimath, P.B., Eds., Horticulture and Livelihood Security, Scientific Publishers, New Dehli, 303-339.

[54] Dias, J.S. and Ortiz, R. (2012) Transgenic Vegetable Crops: Progress, Potentials and Prospects. Plant Breeding Reviews, 35, 151-246.

[55] Dias, J.S. (1989) The Use of Molecular Markers in Selection of Vegetables. SECH, Actas de Horticultura, 3, $175-181$.

[56] Dias, J.S. (1991) The Use of Computers in Plant Breeding. SECH, Actas de Horticultura, 8, 367-371.

[57] Dias, J.S. and Ortiz, R. (2012) Transgenic Vegetable Breeding for Nutritional Quality and Health Benefits. Food and Nutrition Sciences, 3, 1209-1219. http://dx.doi.org/10.4236/fns.2012.39159

[58] Dias, J.S. and Ortiz, R. (2013) Transgenic Vegetables for Southeast Asia. In: Holmer, R., Linwattana, G., Nath, P. and 
Keatinge, J.D.H., Eds., Proceedings. Regional Symposium on High Value Vegetables in Southeast Asia: Production, Supply and Demand (SEAVEG 2012), Chiang Mai, 24-26 January 2012, 361-369.

[59] Dias, J.S. and Ortiz, R. (2013) Transgenic Vegetables for 21st Century Horticulture. Acta Horticulturae, 974, 15-30.

[60] Dias, J.C. (2010) Impact of Improved Vegetable Cultivars in Overcoming Food Insecurity. Euphytica, 176, $125-136$. http://dx.doi.org/10.1007/s10681-010-0237-5

[61] Tilman, D. (1999) Global Environmental Impacts of Agricultural Expansion: The Need for Sustainable and Efficient Practices. Proceedings of the National Academy of Sciences of the United States of America, 96, 5995-6000. http://dx.doi.org/10.1073/pnas.96.11.5995

[62] Robertson, G.P. and Swinton, S.M. (2005) Reconciling Agricultural Productivity and Environmental Integrity: A Grand Challenge for Agriculture. Frontiers in Ecology and the Environment, 3, 38-46. http://dx.doi.org/10.1890/1540-9295(2005)003[0038:RAPAEI]2.0.CO;2

[63] Hirel, B., Le Gouis, J., Ney, B. and Gallais, A. (2007) The Challenge of Improving Nitrogen Use Efficiency in Crop Plants: Towards a More Central Role for Genetic Variability and Quantitative Genetics within Integrated Approaches. Journal of Experimental Botany, 58, 2369-2387. http://dx.doi.org/10.1093/jxb/erm097

[64] Foulkes, M.J., Hawkesford, M.J., Barraclough, P.B., Holdsworth, M.J., Kerr, S., Kightley, S. and Shewry, P.R. (2009) Identifying Traits to Improve the Nitrogen Economy of Wheat: Recent Advances and Future Prospects. Field Crops Research, 114, 329-342. http://dx.doi.org/10.1016/j.fcr.2009.09.005

[65] Korkmaz, K., Ibrikci, H., Karnez, E., Buyuk, G., Ryan, J., Ulger, A.C. and Oguz, H. (2009) Phosphorus Use Efficiency of Wheat Genotypes Grown in Calcareous Soils. Journal of Plant Nutrition, 32, 2094-2106. http://dx.doi.org/10.1080/01904160903308176

[66] Farooq, M., Kobayashi, N., Wahid, A., Ito, O. and Basra, S.M.A. (2009) Strategies for Producing More Rice with Less Water. Advances in Agronomy, 101, 351-388. http://dx.doi.org/10.1016/S0065-2113(08)00806-7

[67] Shi, W., Moon, C.D., Leahy, S.C., Kang, D., Froula, J., Kittelmann, S., Fan, C., Deutsch, S., Gagic, D., Seedorf, H., Kelly, W.J., Atua, R., Sang, C., Soni, P., Li, D., Pinares-Patiño, C.S., Mcewan, J.C., Janssen, P.H., Chen, F., Visel, A., Wang, Z., Attwood, G.T. and Rubin, E.M. (2014) Methane Yield Phenotypes Linked to Differential Gene Expression in the Sheep Rumen Microbiome. Genome Research, 24, 1517-1525. http://dx.doi.org/10.1101/gr.168245.113

[68] Shrawat, A.K. and Good, A.G. (2008) Genetic Engineering Approaches to Improving Nitrogen Use Efficiency. Plant Research News. ISB Report, May 2008. Information Systems for Biotechnology (ISB) News Report, Blackburg. http://www.isb.vt.edu/news/2008/news08.may.htm\#may0801

[69] Daemrich, A., Reinhardt, F. and Shelman, M. (2008) Arcadia Biosciences: Seeds of Change. Harvard Business School, Boston.

[70] Subbarao, G.V., Tomohiro, B., Masahiro, K., Osamu, I., Samejima, H., Wang, H.Y., Pearse, S.J., Gopalakrishnan, S., Nakahara, K., Zakir Hossain, A.K.M., Tsujimoto, H. and Berry, W.L. (2007) Can Biological Nitrification Inhibition (BNI) Genes from Perennial Leymus racemosus (Triticeae) Combat Nitrification in Wheat Farming? Plant and Soil, 299, 55-64. http://dx.doi.org/10.1007/s11104-007-9360-z

[71] IPCC (Intergovernmental Panel on Climate Change) (2009) The Physical Science Basis. In: Solomon, S., Qin, D., Manning, M., Chen, Z., Marquis, M., Averyt, K.B., Tignor, M. and Miller, H.L., Eds., Contribution of Working Group I to the Fourth Assessment Report of the Intergovernmental Panel on Climate Change, Cambridge University Press, Cambridge.

[72] Ortiz, R., Sayre, K.D., Govaerts, B., Gupta, R., Subbarao, G.V., Ban, T., Hodson, D., Dixon, J.M., Ortiz-Monasterio, J.I. and Reinolds, M. (2008) Climate Change: Can Wheat Beat the Heat? Agriculture, Ecosystems \& Environment, 126, 46-58. http://dx.doi.org/10.1016/j.agee.2008.01.019

[73] Araus, J., Slafer, G., Royo, C. and Serret, M.D. (2008) Breeding for Yield Potential and Stress Adaptation in Cereals. Critical Reviews in Plant Sciences, 27, 377-412. http://dx.doi.org/10.1080/07352680802467736

[74] Cattivelli, L., Rizza, F., Badeck, F.W., Mazzucoteli, E., Mastrangelo, A.M., Francia, E., MarÈ, C., Tondelli, A. and Stanca, A.M. (2008) Drought Tolerance Improvement in Crop Plants: An Integrated View from Breeding to Genomics. Field Crops Research, 105, 1-14. http://dx.doi.org/10.1016/j.fcr.2007.07.004

[75] Ceccarelli, S. and Grando, S. (2007) Decentralized-Participatory Plant Breeding: An Example of Demand Driven Research. Euphytica, 155, 349-360. http://dx.doi.org/10.1007/s10681-006-9336-8

[76] Burke, M.B., Lobell, D.B. and Guarino, L. (2009) Shifts in African Crop Climates by 2050, and the Implications for Crop Improvement and Genetic Resources Conservation. Global Environmental Change, 19, 317-325. http://dx.doi.org/10.1016/j.gloenvcha.2009.04.003

[77] Jarvis, D.I., Brown, A.H.D., Cuong, P.H., Collado-Panduro, L., Latoumerie-Moreno, L., Gyawali, S., Tanto, T., Sawadogo, M., Mar, I., Sadiki, M., Hue, N.T., Arias-Reyes, L., Balma, D., Bajracharya, J., Castillo, F., Rijal, D., Belqadi, L., Rana, R., Saidi, S., Quedraogo, J., Zangre, R., Rhrib, K., Chavez, J.L., Schoen, D., Shapit, B., Santis, P.D., Fadda, 
C. and Hodgkin, T. (2008) A Global Perspective of the Richness and Evenness of Traditional Crop-Variety Diversity Maintained by Farming Communities. Proceedings of the National Academy of Sciences of the United States of America, 105, 5326-5331. http://dx.doi.org/10.1073/pnas.0800607105

[78] Witcombe, J.R., Hollington, P.A., Howarth, C.J., Reader, S. and Steele, K.A. (2008) Breeding for Abiotic Stresses for Sustainable Agriculture. Philosophical Transactions of the Royal Society B: Biological Sciences, 363, 703-716. http://dx.doi.org/10.1098/rstb.2007.2179

[79] Bhatnagar-Mathur, P., Vadez, V. and Sharma, K.K. (2007) Transgenic Approaches for Abiotic Stress Tolerance in Plants: Retrospect and Prospects. Plant Cell Reports, 27, 411-424. http://dx.doi.org/10.1007/s00299-007-0474-9

[80] Ainsworth, E., Rogers, A. and Leakey, A.D.B. (2008) Targets for Crop Biotechnology in a Future High-CO ${ }_{2}$ and High-O ${ }_{3}$ World. Plant Physiology, 147, 13-19. http://dx.doi.org/10.1104/pp.108.117101

[81] Ortiz, R. (2008) Crop Genetic Engineering under Global Climate Change. Annals of Arid Zone, 47, 343-354.

[82] Jewell, M.C., Campbell, B.C. and Godwin, I.D. (2010) Transgenic Plants for Abiotic Stress Resistance. In: Kole, C., Michler, C.H., Abbott, A.G. and Hall, T.C., Eds., Transgenic Crop Plants, Springer-Verlag, Berlin-Heidelberg, 67132.

[83] Dwivedi, S.L., Upadhyaya, H., Subudhi, P., Gehring, C., Bajic, V. and Ortiz, R. (2010) Enhancing Abiotic Stress Tolerance in Cereals through Breeding and Transgenic Interventions. Plant Breeding Reviews, 33, 31-114.

[84] Dwivedi, S.L., Sahrawat, K., Upadhyaya, H. and Ortiz, R. (2013) Food, Nutrition and Agrobiodiversity under Global Climate Change. Advances in Agronomy, 120, 1-128. http://dx.doi.org/10.1016/B978-0-12-407686-0.00001-4

[85] Ruane, J., Sonnino, A., Steduto, P. and Deane, C. (2008) Coping with Water Scarcity: What Role for Biotechnologies? Land and Water Discussion Paper 7, Food and Agriculture Organization of the United Nations, Rome.

[86] Sakuma, Y., Maruyama, K., Qin, F., Osakabe, Y., Shinozaki, K. and Yamaguchi-Shinozaki, K. (2006) Dual Function of an Arabidopsis Transcription Factor DREB2A in Water-Stress-Responsive and Heat-Stress-Responsive Gene Expression. Proceedings of the National Academy of Sciences of the United States of America, 103, 18822-18827. http://dx.doi.org/10.1073/pnas.0605639103

[87] Ortiz, R., Iwanaga, M., Reynolds, M.P., Wu, X. and Crouch, J.H. (2007) Overview on Crop Genetic Engineering for Drought-Prone Environments. Journal of SAT Agricultural Research, 4, 1-30.

[88] Pellegrineschi, A., Reynolds, M., Pacheco, M., Brito, R.M., Almeraya, R., Yamaguchi-Shinozaki, K. and Hoisington, D. (2004) Stress-Induced Expression in Wheat of the Arabidopsis thaliana DREB1A Gene Delays Water Stress Symptoms under Greenhouse Conditions. Genome, 47, 493-500. http://dx.doi.org/10.1139/g03-140

[89] Saint Pierre, C.S., Crossa, J.L., Bonnett, D., Yamaguchi-Shinozaki, K. and Reynolds, M.P. (2012) Phenotyping Transgenic Wheat for Drought Resistance. Journal of Experimental Botany, 63, 1799-1808. http://dx.doi.org/10.1093/jxb/err385

[90] Mumms, R. (2005) Genes and Salt Tolerance: Bringing Them Together. New Phytologist, 167, 645-663. http://dx.doi.org/10.1111/j.1469-8137.2005.01487.x

[91] Chinnusamy, V., Jagendorf, A. and Zhu, J.K. (2005) Understanding and Improving Salt Tolerance in Plants. Crop Science, 45, 437-448. http://dx.doi.org/10.2135/cropsci2005.0437

[92] Wu, H.J., Zhang, Z., Wang, J.Y., Oh, D.H., Dassanayake, M., Liu, B., Huang, Q., Sun, H.X., Xia, R., Wu, Y., Wang, Y.N., Yang, Z., Liu, Y., Zhang, W., Zhang, H., Chu, J., Yan, C., Fang, S., Zhang, J., Wang, Y., Zhang, F., Wang, G., Yeol Lee, S., Cheeseman, J.M., Yang, B., Li, B., Min, J., Yang, L., Wang, J., Chu, C., Chen, S.Y., Bohnert, H.J., Zhu, J.K., Wang, X.J. and Xie, Q. (2012) Insights into Salt Tolerance from the Genome of Thellungiella salsuginea. Proceedings of the National Academy of Sciences of the United States of America, 109, 12219-12224. http://dx.doi.org/10.1073/pnas.1209954109

[93] Plett, D., Safwat, G., Gilliham, M., Skrumsager-Møller, I., Roy, S., Shirley, N., Jacobs, A., Johnson, A. and Tester, M. (2010) Improved Salinity Tolerance of Rice through Cell Type-Specific Expression of Athkt1;1. PLoS ONE, 5, e12571. http://dx.doi.org/10.1371/journal.pone.0012571

[94] Moghaieb, R.E., Nakamura, A., Saneoka, H. and Fujita, K. (2011) Evaluation of Salt Tolerance in Ectoine-Transgenic Tomato Plants (Lycopersicon esculentum) in Terms of Photosynthesis, Osmotic Adjustment, and Carbon Partitioning. GM Crops, 2, 58-65. http://dx.doi.org/10.4161/gmcr.2.1.15831

[95] Lybbert, T. and Sumner, D. (2011) Agricultural Technologies for Climate Change Mitigation and Adaptation in Developing Countries: Policy Options for Innovation and Technology Diffusion. ICTSD-IPC Platform on Climate Change. Agriculture and Trade Issues Brief 6. International Centre for Trade and Sustainable Development, Geneva, Switzerland.

[96] Varshney, R.K., Bansal, K.C., Aggarwal, P.K., Datta, S.K. and Craufurd, P.Q. (2011) Agricultural Biotechnology for Crop Improvement in a Variable Climate: Hope or Hype? Trends in Plant Science, 16, 363-371. http://dx.doi.org/10.1016/j.tplants.2011.03.004 
[97] Yamori, W., Hikosaka, K. and Way, D.A. (2013) Temperature Response of Photosynthesis in $\mathrm{C}_{3}, \mathrm{C}_{4}$, and CAM Plants: Temperature Acclimation and Temperature Adaptation. Photosynthesis Research, 119, 101-117. http://dx.doi.org/10.1007/s11120-013-9874-6

[98] Ainsworth, E.A. and Ort, D.R. (2010) How Do We Improve Crop Production in a Warming World? Plant Physiology, 154, 526-530. http://dx.doi.org/10.1104/pp.110.161349

[99] Wahid, A., Gelani, S., Ashraf, M. and Foolad, M.R. (2007) Heat Tolerance in Plants: An Overview. Environmental and Experimental Botany, 61, 199-223. http://dx.doi.org/10.1016/j.envexpbot.2007.05.011

[100] Hasanuzzaman, M., Nahar, K., Alam, Md., Roychowdhury, R. and Fujita, M. (2013) Physiological, Biochemical, and Molecular Mechanisms of Heat Stress Tolerance in Plants. International Journal of Molecular Sciences, 14, 9643-9684. http://dx.doi.org/10.3390/ijms14059643

[101] Gao, H., Brandizzi, F., Benning, C. and Larkin, R.M. (2008) A Membrane-Tethered Transcription Factor Defines a Branch of the Heat Stress Response in Arabidopsis thaliana. Proceedings of the National Academy of Sciences of the United States of America, 105, 16398-16403. http://dx.doi.org/10.1073/pnas.0808463105

[102] Gusta, L. (2012) Abiotic Stresses and Agricultural Sustainability. Journal of Crop Improvement, 26, 415-427. http://dx.doi.org/10.1080/15427528.2011.650296

[103] Katiyar-Agarwal, S., Agarwal, M. and Grover, A. (2003) Heat-Tolerant Basmati Rice Engineered by Over-Expression of hsp101. Plant Molecular Biology, 51, 677-686. http://dx.doi.org/10.1023/A:1022561926676

[104] Pimentel, D. (1997) Techniques for Reducing Pesticide Use: Economic and Environmental Benefits. Wiley, New York.

[105] Oerke, E.C., Dehne, H.W., Schonbeck, F. and Weber, A. (1994) Crop Production and Crop Protection: Estimated Losses in Major Food and Cash Crops. Elsevier, Amsterdam.

[106] Tripathi, L., Mwaka, H., Tripathi, J.N. and Tushemereirwe, W. (2010) Expression of Sweet Pepper Hrap Gene in Banana Enhances Resistance to Xanthomonas campestris pv. Musacearum. Molecular Plant Pathology, 11, 721-731.

[107] Ortiz, R., Jarvis, A., Aggarwal, P.K. and Campbell, B.M. (2014) Plant Genetic Engineering, Climate Change and Food Security. CCAFS Working Paper No. 72. CGIAR Research Program on Climate Change, Agriculture and Food Security (CCAFS), Copenhagen.

[108] Haverkort, A.J., Boonekamp, P.M., Hutten, R., Jacobsen, E., Lotz, L.A.P., Kessel, G.J.T., Visser, R.F.G. and Van Der Vossen, E.A.G. (2008) Societal Costs of Late Blight in Potato and Prospects of Durable Resistance through Cisgenic Modification. Potato Research, 51, 47-57. http://dx.doi.org/10.1007/s11540-008-9089-y

[109] Jacobs, D.F. (2007) Toward Development of Silvical Strategies for Forest Restoration of American Chestnut (Castanea dentata) Using Blight Resistant Hybrids. Biological Conservation, 137, 497-506. http://dx.doi.org/10.1016/j.biocon.2007.03.013

[110] Santini, A., La Porta, N., Ghelardini, L. and Mittempergher, L. (2007) Breeding against Dutch Elm Disease Adapted to the Mediterranean Climate. Euphytica, 163, 45-56. http://dx.doi.org/10.1007/s10681-007-9573-5

[111] Bouton, J. (2007) The Economic Benefits of Forage Improvement in the United States. Euphytica, 154, 263-270. http://dx.doi.org/10.1007/s10681-006-9220-6

[112] Pimentel, D., Allen, J., Beers, A., Guinand, L., Linder, R., Mclaughlin, P., Meer, B., Musonda, D., Perdue, D., Poisson, S., Siebert, S., Stoner, K., Salazar, R. and Hawkinset, A. (1987) World Agriculture and Soil Erosion. Erosion Threatens World Food Production. Bioscience, 37, 277-283. http://dx.doi.org/10.2307/1310591

[113] Glover, J.D., Cox, C.M. and Reganold, J.P. (2007) Future Farming: A Return to Roots? Scientific American, 297, 82-89. http://dx.doi.org/10.1038/scientificamerican0807-82

[114] Jackson, W., Cox, S., Dehaan, L., Glover, J., Van Tassel, D. and Cox, C. (2009) The Necessity and Possibility of an Agriculture Where Nature Is the Measure. In: Bohlen, P.J. and House, G., Eds., Sustainable Agroecosystem Management, CRC Press, Boca Raton, 61-71.

[115] Blanco, H. and Lal, R., Eds. (2008) Principles of Soil Conservation and Management. Springer, New York.

[116] Olson, K.R., Ebelhar, S.A. and Lang, J.M. (2010) Cover Crops Effects on Crop Yields and Soil Organic Content. Soil Science, 175, 89-98. http://dx.doi.org/10.1097/SS.0b013e3181cf7959

[117] Kaumbutho, P. and Kienzle, J. (2008) Conservation Agriculture as Practiced in Kenya: Two Case Studies. Food and Agriculture Organization of the United Nations, Rome.

[118] Pretty, J.N. and Hine, R. (2001) Reducing Food Poverty with Sustainable Agriculture: A Summary of New Evidence. Final Report of the "SAFE-World" (The Potential of Sustainable Agriculture to Feed the World) Research Project. Centre for Environment and Society, University of Essex, Colchester.

[119] Kendle, A.D. and Rose, J.E. (2000) The Aliens Have Landed! What Are the Justifications for "Native Only" Policies in Landscape Plantings? Landscape and Urban Planning, 47, 19-31. http://dx.doi.org/10.1016/S0169-2046(99)00070-5 
[120] Zhao, F.J. and Mcgrath, S.P. (2009) Biofortification and Phytoremediation. Current Opinion in Plant Biology, 12, 373380. http://dx.doi.org/10.1016/j.pbi.2009.04.005

[121] Yin, X., Yuan, L., Liu, Y. and Lin, Z. (2012) Phytoremediation and Biofortification: Two Sides of One Coin. In: Yin, X. and Yuan, L., Eds., Phytoremediation and Biofortification, Springer Briefs in Green Chemistry for Sustainable, Springer, New York, 1-6.

[122] Pilon-Smits, E. (2005) Phytoremediation. Annual Review of Plant Biology, 56, 15-39. http://dx.doi.org/10.1146/annurev.arplant.56.032604.144214

[123] Kramer, U. (2005) Phytoremediation: Novel Approaches to Cleaning up Polluted Soils. Current Opinion in Biotechnology, 16, 133-141. http://dx.doi.org/10.1016/j.copbio.2005.02.006

[124] Doty, S.L. (2008) Enhancing Phytoremediation through the Use of Transgenics and Endophytes. New Phytologist, 179, 318-333. http://dx.doi.org/10.1111/j.1469-8137.2008.02446.x

[125] Chaney, R.L., Angle, J.S., Broadhurst, C.L., Peters, C.A., Tappero, R.V. and Parks, D.L. (2007) Improved Understanding of Hyperaccumulation Yields Commercial Phytoextraction and Phytomining Technologies. Journal of Environmental Quality, 36, 1429-1443. http://dx.doi.org/10.2134/jeq2006.0514

[126] Mcgrath, S.P. and Zhao, F.J. (2003) Phytoextraction of Metals and Metalloids from Contaminated Soils. Current Opinion in Biotechnology, 14, 277-282. http://dx.doi.org/10.1016/S0958-1669(03)00060-0

[127] Murakami, M., Ae, N., Ishikawa, S., Ibaraki, T. and Ito, M. (2008) Phytoextraction by a High-Cd-Accumulating Rice: Reduction of Cd Content of Soybean Seeds. Environmental Science \& Technology, 42, 6167-6172. http://dx.doi.org/10.1021/es8001597

[128] Ueno, D., Kono, I., Yokosho, K., Ando, T., Yano, M. and Ma, J.F. (2009) A Major Quantitative Trait Locus Controlling Cadmium Translocation in Rice (Oryza sativa). New Phytologist, 182, 644-653. http://dx.doi.org/10.1111/j.1469-8137.2009.02784.x

[129] Grant, C.A., Clarke, J.M., Duguid, S. and Chaney, R.L. (2008) Selection and Breeding of Plant Cultivars to Minimize Cadmium Accumulation. Science of the Total Environment, 390, 301-310. http://dx.doi.org/10.1016/j.scitotenv.2007.10.038

[130] Mcgrath, S.P., Lombi, E., Gray, C.W., Caille, N., Dunham, S.J. and Zhao, F.J. (2006) Field Evaluation of Cd and Zn Phytoextraction Potential by the Hyperaccumulators Thlaspi caerulescens and Arabidopsis halleri. Environmental Pollution, 141, 115-125. http://dx.doi.org/10.1016/j.envpol.2005.08.022

[131] Maxted, A.P., Black, C.R., West, H.M., Crout, N.M.J., Mcgrath, S.P. and Young, S.D. (2007) Phytoextraction of Cadmium and Zinc from Arable Soils Amended with Sewage Sludge Using Thlaspi caerulescens: Development of a Predictive Model. Environmental Pollution, 150, 363-372. http://dx.doi.org/10.1016/j.envpol.2007.01.021

[132] Zhao, F.J., Hamon, R.E., Lombi, E., Mclaughlin, M.J. and Mcgrath, S.P. (2002) Characteristics of Cadmium Uptake in Two Contrasting Ecotypes of the Hyperaccumulator Thlaspi caerulescens. Journal of Experimental Botany, 53, 535543. http://dx.doi.org/10.1093/jexbot/53.368.535

[133] Kertulis-Tartar, G.M., Ma, L.Q., Tu, C. and Chirenje, T. (2006) Phytoremediation of an Arsenic-Contaminated Site Using Pteris vittata L.: Two-Year Study. International Journal of Phytoremediation, 8, 311-322. http://dx.doi.org/10.1080/15226510600992873

[134] Salido, A.L., Hasty, K.L., Lim, J.M. and Butcher, D.J. (2003) Phytoremediation of Arsenic and Lead in Contaminated Soil Using Chinese Brake Ferns (Pteris vittata) and Indian Mustard (Brassica juncea). International Journal of Phytoremediation, 5, 89-103. http://dx.doi.org/10.1080/713610173

[135] Dickinson, N.M. and Pulford, I.D. (2005) Cadmium Phytoextraction Using Short-Rotation Coppice Salix: The Evidence Trail. Environment International, 31, 609-613. http://dx.doi.org/10.1016/j.envint.2004.10.013

[136] Wieshammer, G., Unterbrunner, R., Garcia, T.B., Zivkovic, M.F., Puschenreiter, M. and Wenzel, W.W. (2007) Phytoextraction of Cd and Zn from Agricultural Soils by Salix ssp. and Intercropping of Salix caprea and Arabidopsis halleri. Plant and Soil, 298, 255-264. http://dx.doi.org/10.1007/s11104-007-9363-9

[137] Lievens, C., Yperman, J., Cornelissen, T. and Carleer, R. (2008) Study of the Potential Valorisation of Heavy Metal Contaminated Biomass via Phytoremediation by Fast Pyrolysis. Part II. Characterisation of the Liquid and Gaseous Fraction as a Function of the Temperature. Fuel, 87, 1906-1916. http://dx.doi.org/10.1016/j.fuel.2007.10.023

[138] Rooney, W., Blumenthal, J., Bean, B. and Mullet, J. (2007) Designing Sorghum as a Dedicated Bioenergy Feedstock. Biofuels, Bioproducts and Biorefining, 1, 147-157. http://dx.doi.org/10.1002/bbb.15

[139] Jessup, R.W. (2009) Development and Status of Dedicated Energy Crops in the United States. In Vitro Cellular \& Developmental Biology-Plant, 45, 282-290.

[140] Robertson, G.P., Dale, V.H., Doering, O.C., Hamburg, S.P., Melillo, J.M., Wander, M.M., Parton, W.J., Adler, P.R., Barney, J.N., Cruse, R.M., Duke, C.F., Fearnside, P.M., Follett, R.F., Gibbs, H.K., Goldemberg, J., Mladenoff, D.J., 
Ojima, D., Palmer, M.W., Sharpley, A., Wallace, L., Weathers, K.C., Wiens, J.A. and Wilhelm, W.W. (2008) Sustainable Biofuels Redux. Science, 322, 49-50. http://dx.doi.org/10.1126/science.1161525

[141] Cook, R.J. (2006) Toward Cropping Systems that Enhance Productivity and Sustainability. Proceedings of the National Academy of Sciences of the United States of America, 103, 18389-18394. http://dx.doi.org/10.1073/pnas.0605946103

[142] Carpenter, J. (2011) Impacts of GM Crops on Biodiversity. GM Crops, 2, 7-23. http://dx.doi.org/10.4161/gmcr.2.1.15086

[143] Icoz, I. and Stotzky, G. (2008) Fate and Effects of Insect-Resistant Bt Crops in Soil Ecosystems. Soil Biology and Biochemistry, 40, 559-586. http://dx.doi.org/10.1016/j.soilbio.2007.11.002

[144] Hoheisel, G.A. and Fleischer, S.J. (2007) Coccinelids, Aphids, and Pollen in Diversified Vegetable Fields with Transgenic and Isoline Cultivars. Journal of Insect Science, 7, 1-12. http://dx.doi.org/10.1673/031.007.6101

[145] Leslie, T.W., Hoheisel, G.A., Biddinger, D.J., Rohr, J.R. and Fleisher, S.J. (2007) Transgenes Sustain Epigeal Insect Biodiversity in Diversified Vegetable Farm Systems. Environmental Entomology, 36, 234-244. http://dx.doi.org/10.1603/0046-225X(2007)36[234:TSEIBI]2.0.CO;2

[146] Jørgensen, R.B. and Andersen, B. (1994) Spontaneous Hybridization between Oilseed Rape (Brassica napus) and Weedy B. campestris (Brassicaceae): A Risk of Growing Genetically Modified Oilseed Rape. American Journal of Botany, 81, 1620-1626. http://dx.doi.org/10.2307/2445340

[147] Hansen, L.B., Siegismund, H.R. and Jørgensen, R.B. (2003) Progressive Introgression between Brassica napus (Oilseed Rape) and B. rapa. Heredity, 91, 276-283. http://dx.doi.org/10.1038/sj.hdy.6800335

[148] Stewart Jr., C.N., Halfhill, M.D. and Warwick, S.I. (2003) Transgene Introgression from Genetically Modified Crops to Their Wild Relatives. Nature Reviews Genetics, 4, 806-817. http://dx.doi.org/10.1038/nrg1179

[149] Brown, J. and Brown, A.P. (1996) Gene Transfer between Canola (Brassica napus and B. campestris) and Related Weed Species. Annals of Applied Biology, 129, 513-522. http://dx.doi.org/10.1111/j.1744-7348.1996.tb05773.x

[150] Mikkelsen, T.R., Anderson, B. and Jorgensen, R.B. (1996) The Risk of Crop Transgene Spread. Nature, 380, 31. http://dx.doi.org/10.1038/380031a0

[151] Boudry, P., Broomberg, K., Saumitou-Laprade, P., Morchen, M., Cuegen, J. and Van Dijk, H. (1994) Gene Escape in Transgenic Sugar Beet: What Can Be Learned from Molecular Studies of Weed Beet Populations? Proceedings of the 3rd International Symposium on the Biosafety, Results of Field Tests of Genetically-Modified Plants and Microorganisms, University of California, Division of Agriculture and Natural Resources, Oakland, 75-83.

[152] Rose, C.W., Millwood, R.J., Moon, H.S., Rao, M.R., Halfhill, M.D., Raymer, P.L., Warwick, S.I., Al-Ahmad, H., Gressel, J. and Stewart Jr., C.N. (2009) Genetic Load and Transgenic Mitigating Genes in Transgenic Brassica rapa (Field Mustard) × Brassica napus (Oilseed Rape) Hybrid Populations. BMC Biotechnology, 9, 93. http://dx.doi.org/10.1186/1472-6750-9-93

[153] Palaudelmàs, M., Peñas, G., Mele, E., Serra, J., Salvia, J., Pla, M., Nadal, A. and Messeguer, J. (2009) Effect of Volunteers on Maize Gene Flow. Transgenic Research, 18, 583-594. http://dx.doi.org/10.1007/s11248-009-9250-7

[154] Carpenter, J.E. (2010) Peer-Reviewed Surveys Indicate Positive Impact of Commercialized GM Crops. Nature Biotechnology, 28, 319-321. http://dx.doi.org/10.1038/nbt0410-319

[155] Brookes, G., Yu, T.H., Tokgoz, S. and Elobeid, A. (2010) The Production and Price Impact of Biotech Corn, Canola, and Soybean Rops. AgBioForum, 13, 25-52.

[156] Storer, N.P., Dively, G.P. and Herman, R.A. (2008) Landscape Effects of Insect-Resistant Genetically Modified Crops. In: Romeis, J., Shelton, A.M. and Kennedy, G.G., Eds., Integration of Insect-Resistant Genetically Modified Crops within IPM Programs, Springer, New York, 273-302.

[157] Naranjo, S.E. (2005) Field Studies Assessing Arthropod Non-Target Effects of Bt Transgenic Crops: Introduction. Environmental Entomology, 34, 1178-1180.

[158] Naranjo, S.E. (2005) Long-Term Assessment of the Effects of Transgenic Bt Cotton on the Abundance of Non-Target Arthropod Natural Enemies. Environmental Entomology, 34, 1193-1210. http://dx.doi.org/10.1603/0046-225X(2005)034[1193:LAOTEO]2.0.CO;2

[159] Naranjo, S.E. (2005) Long-Term Assessment of the Effects of Transgenic Bt Cotton on the Function of the Natural Enemy Community. Environmental Entomology, 34, 1211-1223. http://dx.doi.org/10.1603/0046-225X(2005)034[1211:LAOTEO]2.0.CO;2

[160] Wolfenbarger, L.L., Naranjo, S.E., Lundgren, J.G., Bitzer, R.J. and Watrud, L.S. (2008) Bt Crop Effects on Functional Guilds of Non-Target Arthropods: A Meta-Analysis. PLoS ONE, 3, e2118. http://dx.doi.org/10.1371/journal.pone.0002118

[161] Naranjo, S.E. (2009) Impacts of Bt Crops on Non-Target Invertebrates and Insecticide Use Patterns. CAB Reviews: 
Perspectives in Agriculture, Veterinary Science, Nutrition and Natural Resources, 4, 1-23. http://dx.doi.org/10.1079/PAVSNNR20094011

[162] Duan, J.J., Lundgren, J.G., Naranjo, S. and Marvier, M. (2009) Extrapolating Non-Target Risk of Bt Crops from Laboratory to Field. Biology Letters, 6, 74-77. http://dx.doi.org/10.1098/rsbl.2009.0612

[163] Brookes, G. and Barfoot, P. (2012) Global Economic and Environmental Benefits of GM Crops Continue to Rise. PG Economics 2012. http://www.pgeconomics.co.uk/page/33/global-impact-2012

[164] Bennet, R., Phipps, R., Strange, A. and Grey, P. (2004) Environmental and Human Health Impacts of Growing Genetically Modified Herbicide-Tolerant Sugar Beet: A Life-Cycle Assessment. Plant Biotechnology Journal, 2, 273-278. http://dx.doi.org/10.1111/j.1467-7652.2004.00076.x

[165] National Research Council (2010) The Impact of Genetically Engineered Crops on Farm Sustainability in the United States. National Academies, Washington DC.

[166] Wang, S., Just, D.R. and Pinstrup-Andersen, P. (2008) Bt-Cotton and Secondary Pests. International Journal of Biotechnology, 10, 113-120. http://dx.doi.org/10.1504/IJBT.2008.018348

[167] Wang, Z.J., Lin, H., Huang, J., Hu, R., Rozelle, S. and Pray, C. (2009) Bt Cotton in China: Are Secondary Insect Infestations Offsetting the Benefits in Farmer Fields? Agricultural Sciences in China, 8, 83-90. http://dx.doi.org/10.1016/S1671-2927(09)60012-2

[168] Gassmann, A.J., Petzold-Maxwell, J.L., Keweshan, R. and Dunbar, M.W. (2011) Field-Evolved Resistance to Bt Maize by Western Corn Rootworm. PLOS ONE, 6, e22629. http://dx.doi.org/10.1371/journal.pone.0022629

[169] Fowler, C. (2011) Conserving Diversity: The Challenge of Cooperation. Acta Horticulturae, 916, 19-24.

[170] Ortiz, R., Mowbray, D., Dowswell, C. and Rajaram, S. (2007) Norman E. Borlaug: The Humanitarian Plant Scientist Who Changed the World. Plant Breeding Reviews, 28, 1-37. http://dx.doi.org/10.1002/9780470168028.ch1

[171] Ortiz, R., Braun, H.J., Crossa, J., Crouch, J.H., Davenport, G., Dixon, J., Dreisigacker, S., Duveiller, E., He, Z., Huerta, J., Joshi, A.K., Kishii, M., Kosina, P., Manes, Y., Mezzalama, M., Morgounov, A., Murakami, J., Nicol, J., Ortiz-Ferrara, G., Ortiz-Monasterio, J.I., Payne, T.S., Peña, R.J., Reynolds, M.P., Sayre, K.D., Sharma, R.C., Singh, R.P., Wang, J., Warburton, M., Wu, H. and Iwanaga, M. (2008) Wheat Genetic Resources Enhancement by the International Maize and Wheat Improvement Center (CIMMYT). Genetic Resources and Crop Evolution, 55, 1095-1140. http://dx.doi.org/10.1007/s10722-008-9372-4

[172] Reynolds, M.P. and Borlaug, N.E. (2006) International Collaborative Wheat Improvement: Impacts and Future Prospects. Journal of Agricultural Science, 144, 3-17. http://dx.doi.org/10.1017/S0021859606005867

[173] Lantican, M.A., Dubin, M.J. and Morris, M.L. (2005) Impacts of International Wheat Breeding Research in the Developing World, 1988-2002. Centro Internacional de Mejoramiento de Maíz y Trigo, México D.F.

[174] Alston, J.M., Marra, M.C., Pardey, P.G. and Wyatt, T.J. (2000) Research Returns Redux: A Meta-Analysis of the Returns to Agricultural R\&D. Australian Journal of Agricultural and Resource Economics, 44, 185-215. http://dx.doi.org/10.1111/1467-8489.00107

[175] Evenson, R.E. and Gollin, D. (1997) Genetic Resources, International Organizations, and Improvement in Rice Varieties. Economic Development and Cultural Change, 45, 471-500. http://dx.doi.org/10.1086/452288

[176] Jackson, M.T. and Huggan, R.D. (1993) Sharing the Diversity of Rice to Feed the World. Diversity, 9, 22-25.

[177] Salhuana, W. and Pollak, L. (2006) Latin American Maize Project (LAMP) and Germplasm Enhancement of Maize (GEM) Project: Generating Useful Breeding Germplasm. Maydica, 51, 339-355.

[178] Taba, S., Díaz, J., Franco, J., Crossa, J. and Eberhart, S.A. (1999) A Core Subset of LAMP from the Latin American Maize Project. CD-Rom. Centro Internacional de Mejoramiento de Maíz y Trigo, México D.F.

[179] Balint-Kurti, P., Blanco, M., Milard, M., Duvick, S., Holland, J., Clements, M., Holley, R., Carson, M.L. and Goodman, M. (2006) Registration of 20 GEM Maize Breeding Germplasm Lines Adapted to the Southern USA. Crop Science, 46, 996-998. http://dx.doi.org/10.2135/cropsci2005.04-0013

[180] Goodman, M.M. (2005) Broadening the U.S. Maize Germplasm Base. Maydica, 50, 203-214.

[181] Ortiz, R., Taba, S., Chávez-Tovar, V.H., Mezzalama, M., Xu, Y., Yan, J. and Crouch, J.H. (2010) Conserving and Enhancing Maize Genetic Resources as Global Public Goods-A Perspective from CIMMYT. Crop Science, 50, 13-28. http://dx.doi.org/10.2135/cropsci2009.06.0297

[182] Delmer, D.P. (2005) Agriculture in the Developing World: Connecting Innovations in Plant Research to Downstream Applications. Proceedings of the National Academy of Sciences of the United States of America, 102, 15739-15746. http://dx.doi.org/10.1073/pnas.0505895102 
Scientific Research Publishing (SCIRP) is one of the largest Open Access journal publishers. It is currently publishing more than 200 open access, online, peer-reviewed journals covering a wide range of academic disciplines. SCIRP serves the worldwide academic communities and contributes to the progress and application of science with its publication.

Other selected journals from SCIRP are listed as below. Submit your manuscript to us via either submit@scirp.org or Online Submission Portal.
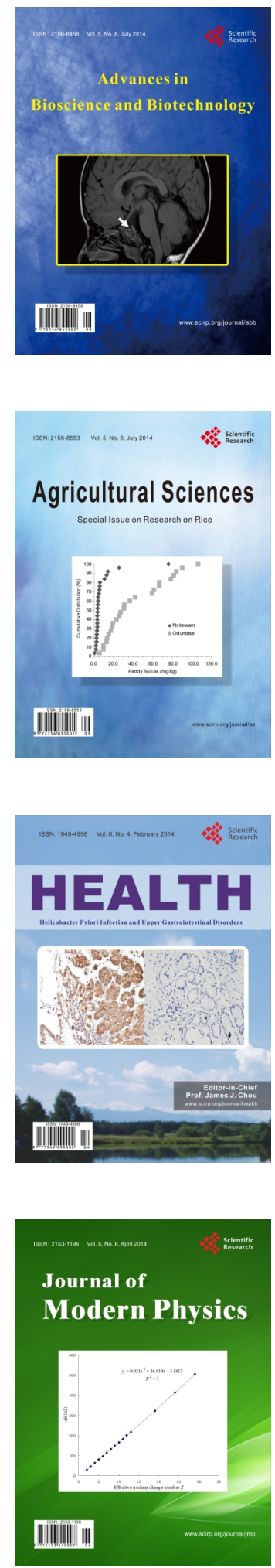
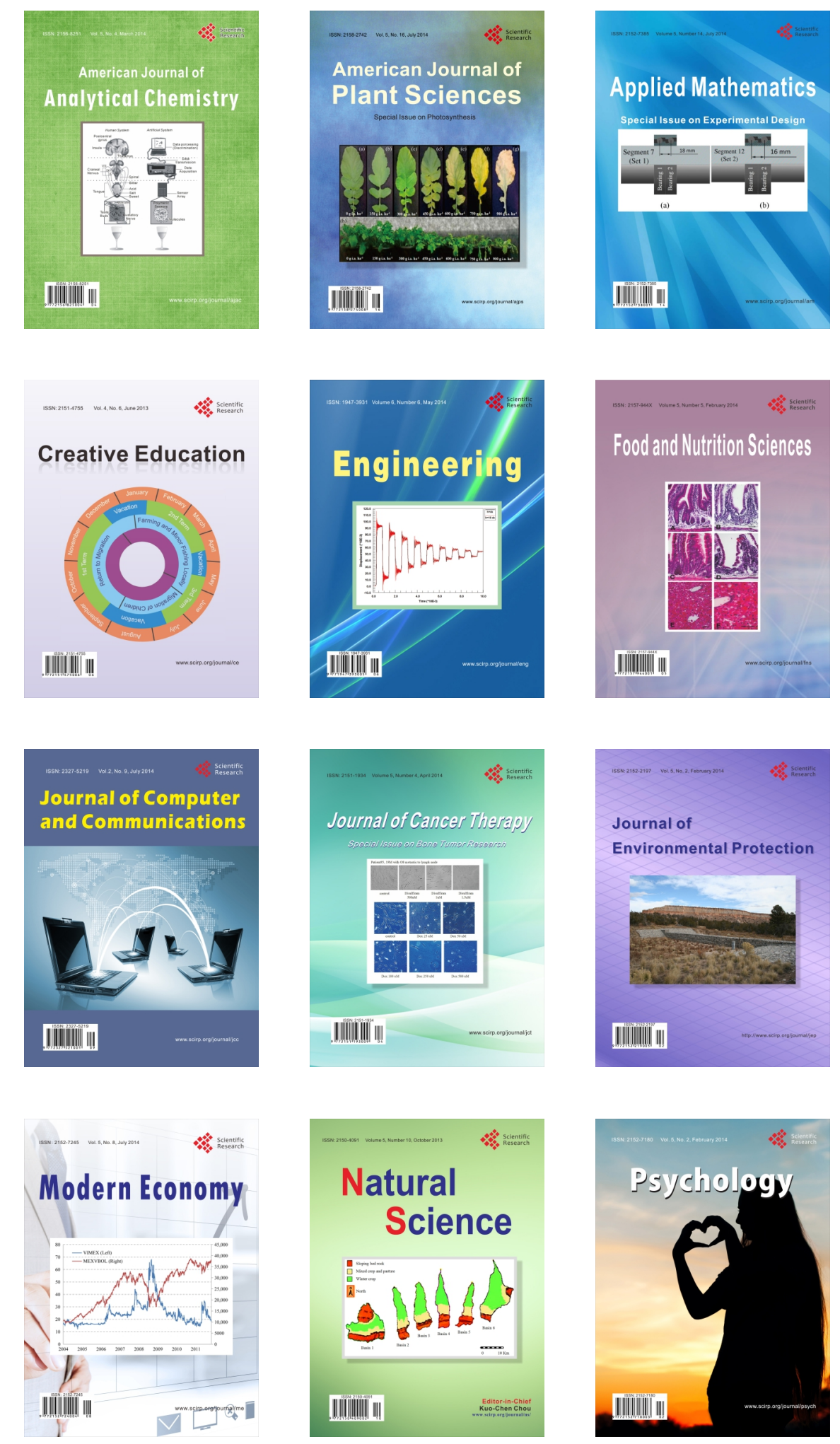